\title{
Parametre Kestirimi Newton-Raphson Yöntemiyle Yapılan MATLAB/GUI Tabanlı Fotovoltaik Sistem Simülatörü
}

\author{
İbrahim BULDU a, (1), Mustafa Ergin ŞAHIN ${ }^{\text {b, }}$ \\ ${ }^{a},{ }^{*}$ RTE Üniversitesi, Mühendislik-Mimarlık Fakültesi, Enerji Sistemleri Mühendisliği Bölümü, 53100, Rize, Türkiye \\ ${ }^{b}$ RTE Üniversitesi, Mühendislik-Mimarlık Fakültesi, Elektrik Elektronik Mühendisliği Bölümü, 53100, Rize, Türkiye
}

\begin{tabular}{l} 
MAKALE \\
BİLGISI \\
\hline $\begin{array}{l}\text { Alınma: } 23.05 .2021 \\
\text { Kabul: } 09.11 .2021\end{array}$ \\
Anahtar Kelimeler: \\
Fotovoltaik güneş pili, \\
Fotovoltaik güneş pili \\
modülü ve modelleri, \\
MATLAB GUI \\
simülasyonu, \\
Newton-Raphson \\
metodu
\end{tabular}

$\ddot{0} \mathbf{Z}$

Bu çalışmada ilk olarak güneş pilinin çalışma prensibi, bileşenleri ve bağlantı şekilleri ile eşdeğer devre modeli çıkarımı incelenmiştir. Fotovoltaik (FV) güneş pili modülü genel eşdeğer devre modeli matematiksel denklemleri MATLAB programına uyarlanmıştır. Güneş pilinin akım denklemi çözümü için Newton-Raphson yöntemi kullanılarak MATLAB grafiksel kullanıcı ara yüzü (GUI) ortamında bir ara yüz olușturulmuștur. Kullanılan model güneș 1șınımı ve sıcaklık gibi değişen çevresel koşulları da içerecek şekilde tasarlanmıştır. Oluşturulan ara yüz ile kullanıcı; 1şınım, sıcaklık, seri direnç, ideallik faktörü ve seri-paralel bağlı hücre sayıları gibi parametreleri değiştirerek akım ile gerilim $(I-V)$ ve güç ile gerilim $(P-V)$ eğrilerini kolayca elde edebilmektedir. $\mathrm{Bu}$ çalışmada iki ayrı üretici firmaya ait güneş paneli verileri için farklı parametreler kullanılarak karakteristik eğriler elde edilmiştir. Ayrıca kullanıcı bu ara yüz sayesinde fotovoltaik hücrenin değişken değerlerini girerek maksimum akım $\left(I_{m p}\right)$, maksimum gerilim $\left(V_{m p}\right)$, maksimum güç $\left(P_{m p}\right)$, giriş gücü $\left(P_{i n}\right)$, doldurma faktörü $(D F)$ ve verim $(\eta)$ gibi değerleri kolaylıkla elde edebilmektedir. Bu sayede bu alanda çalışanlar için kullanıcıya kolaylık sağlayan bir ara yüz geliştirilmiştir.

https://dx.doi.org/10.30855/gmbd.2021.03.03

\section{A MATLAB/GUI Based Photovoltaic System Simulator for Estimation of PV Parameter using Newton-Raphson Method}

\begin{tabular}{l} 
ARTICLE \\
INFO \\
\hline \\
Received: 23.05 .2021 \\
Accepted: 09.11 .2021 \\
\hline \\
Keywords: \\
Photovoltaic solar cell, \\
Photovoltaic solar cell \\
module and models, \\
MATLAB GUI \\
simulation, \\
Newton Rapson \\
method
\end{tabular}

\begin{abstract}
In this study, the working principle, components and connection types of the solar cell and the equivalent circuit model extraction were examined. The mathematical equations of the photovoltaic (PV) solar cell module general equivalent circuit model were adapted to the MATLAB software. An interface was created in the MATLAB GUI environment using the Newton-Raphson method to solve the current equation of the solar cell. The model used also includes changing environmental conditions such as solar radiation and temperature. With the interface created, the user; can quickly obtain Current-Voltage $(I-V)$ and Power-Voltage $(P-V)$ curves by changing parameters such as radiation, temperature, series resistance, ideality factor and number of cells connected in series-parallel. In this study, characteristic curves were obtained by using different parameters for the solar panel data of two other manufacturers. In addition, the user can quickly get values such as maximum current $\left(I_{m p}\right)$, maximum voltage $\left(V_{m p}\right)$, maximum power $\left(P_{m p}\right)$, input power $\left(P_{i n}\right)$, filling factor $(F F)$ and efficiency $(\eta)$ by entering the variable values of the photovoltaic cell through this interface. In this way, an interface that provides convenience to the user has been developed for those working in this field.
\end{abstract}

https://dx.doi.org/10.30855/gmbd.2021.03.03

\section{GIRISS (INTRODUCTION)}

*Sorumlu yazar: mustafaerginsahin@yahoo.com

To cite this article: İ. Buldu ve M.E. Şahin, "A MATLAB/GUI based photovoltaic system simulator for estimation of PV parameter using Newton-Raphson method”, Gazi Journal of Engineering Sciences, vol.7, no.3, pp. 196-212, 2021. doi:10.30855/gmbd.2021.03.03 
Günümüzde fosil yakıtların dışa bağımlı olması ve fosil yakıtların sınırlı kaynaklara sahip olması yanında küresel ısınma ve çevre kirliliğini arttırması gibi nedenlerden dolayı sürdürülebilir bir enerji kaynağı olmadığı görülmektedir. Fosil yakıtların neden olduğu sorunlar ve yok edilmesi için gerekli maliyetlerin çok yüksek olması, enerji üretiminde temiz ve sürdürülebilir enerji kaynaklarını gündeme getirmiş ve yenilenebilir enerji kaynakları keşfedilmiştir [1]. Güneşten gelen enerji günümüzde 1s1 enerjisine dönüştürülerek yâda elektrik enerjisine dönüştürülerek kullanılmaktadır [2]. Güneș enerjisi 1s1 enerjisine dönüştürülürken "toplaçlar"; elektrik enerjisine dönüştürülürken de "güneş gözeleri- güneş pilleri” kullanılmaktadır [3].

Güneş gözeleri doğrudan güneş enerjisini elektrik enerjisine çevirir. Bu sistemlerde güneş takip sistemi ve güç elektroniği dönüştürücüleri kullanılarak sürekli var olan en yüksek güneş enerjisi miktarı elde edilir. Günümüzde güneş enerjisinden elektrik elde edilen güneş elektrik santralleri (GES) ve güneş enerjisini elektrik enerjisine çeviren güneş panelleri giderek yaygın olarak kullanılmaya başlamıştır [4]. Güneş panellerinin verimi pillerin iç dirençleri, üretildiği malzeme, kontak yapıları, ışık şiddeti ve sıcaklık değişimi gibi parametrelere bağlı olarak değişmektedir. $\mathrm{Bu}$ sebeple güneş pilleri ile ilgili yapılacak olan çalışmalarda daha doğru sonuçlara ulaşabilmek için bu değerlerin güneş pillerinin verimini nasıl etkileyeceğini ortaya koyacak bir model oluşturulması gerekir [5]. Günümüze ulaşan fotovoltaik hücre modellemesine ilişkin birçok bilimsel çalışma ortaya konmuş olup geliştirilen yeni FV sistemlerle ilgili araştırmalarda devam etmektedir [6-12].

$\mathrm{Bu}$ konuda yapılan çalışmalar incelendiğinde FV hücre modellemesi için çeşitli varsayımlarda bulunulduğu görülmektedir. $\mathrm{Bu}$ yaklaşımlar, tek diyotlu ve dirençli eşdeğer devre modeli, tek diyotlu ve iki dirençli eşdeğer devre modeli, iki diyotlu ve iki dirençli eşdeğer devre modelleridir [13-18]. Tek diyotlu olan model üstel olarak ifade edilmekte ve tek üstel ifade içermekte, iki diyotlu olan model ise çift üstel model olarak bilinmektedir. Tek diyotlu model iki diyotlu modele göre daha basit olduğundan benzetim çalışmaları için daha kapsamlı bir kullanımı vardır. Ancak iki diyotlu olan modelde, çift üstel ifade bulunduğundan sicaklık ve 1şınıma bağlı parametrelerin bulunması daha zordur ancak daha doğru sonuç verir [19].

Literatüre bakıldığında Bayındır ve diğerleri tarafından yapılan benzer çalışmada güneş paneline
MATLAB/Simulink programı ile modelleme yapılarak MATLAB/GUI ile bir kullanıcı ara yüzü oluşturulmuş, ancak bu çalışmada sadece 1şınım ve sıcaklık parametreleri değiştirilerek iki farklı fotovoltaik modüle ait karakteristik eğrileri çizdirilmiştir [17]. Şahin ve Okumuş' un yaptığı çalışmada ise güneş modülünün karakteristik eğrileri farklı parametreler için doğrulanmıştır, ancak kullanıcıların değişimini görmek istediği parametre için kod üzerinden ilgili parametreyi değiştirmesi gerekmektedir [20]. Türkmenoğlu ve Güngör tarafindan MATLAB/Simulink ve MATLAB/GUI ortamında ile aynı özelliklere sahip güneş pili modellenmiş ve her iki sistemde de 1 şınım ve sıcaklık değeri, seri ve paralel direnç ve hücre sayıları gibi etkenleri değiştirerek FV hücre ve modül karakteristiklerinin incelendiğini söylemişler ancak MATLAB/Simulink modelinde sadece $1000 \mathrm{~W} / \mathrm{m}^{2}$ radyasyon, $25^{\circ} \mathrm{C}$ sabit sıcaklık, $0.001 \Omega$ seri direnç ve $1000 \Omega$ paralel direnç değerleri için FV hücre, modül ve dizinin karakteristik eğrileri gösterilmiştir. MATLAB/GUI modelinde ise ayn1 parametre değerlerinde yalnız FV hücrenin karakteristik eğrileri verilmiştir [12]. Eteiba ve arkadaşları yaptıkları çalışmada FV hücre, modül ve dizi simülasyonu için MATLAB/GUI ara yüzü oluşturmuş, oluşturulan ara yüz ile farklı ışınım ve sıcaklık değerleri değiştirilerek karakteristik eğrileri elde edilmiş ancak diğer parametrelerin değişimi incelenmemiştir [21].

Yapılan çalışmada ise; öncelikle güneş pillerinin yapısı, matematiksel denklemleri ve eşdeğer devre modeli verilmiştir. Tek diyotlu fotovoltaik pilin basitleştirilmiş eşdeğer devresi üzerinden güneş pilinin genel matematiksel benzetim modeli MATLAB programına uyarlanmış ve modele ilişkin bir arayüz tasarımı gerçekleştirilmiştir. $\mathrm{Bu}$ arayüz kullanıcıya kolaylık sağlayan ve grafiksel bir arayüz yapısına sahip olan MATLAB/GUI programında hazırlanmıştır. $\mathrm{Bu}$ arayüz ile kullanıcı seri ve paralel hücre sayısı ile sıcaklık değerleri, güneş ışınımı gibi güneş pili parametrelerine göre $I-V$ ve $P-V$ eğrilerini kolay ve hızlı bir şekilde inceleyebilir. Yine kullanıcı bu arayüz sayesinde fotovoltaik hücre değişken değerlerini girerek maksimum akım $\left(I_{m p}\right)$, maksimum gerilim $\left(V_{m p}\right)$, maksimum güç $\left(P_{m p}\right)$, giriş gücü $\left(P_{i n}\right)$, doldurma faktörü $(D F)$ ve verim $(\eta)$ değerlerini kolayca elde edebilir. Bu arayüz ile bu alanda çalışan öğrenci, araştırmacıların ve panel üreticilerinin hiçbir kod veya program yazmaya gerek duymadan istediği değişkeni değiştirip fotovoltaik hücre karakteristik eğrilerini ve ilgili değerleri hızlı ve kolay bir biçimde elde etmesi amaçlanmıştır. 
2. GÜNEŞ PILIININ YAPISI, MATEMATIKSEL MODELİ ÇIKARIMI VE EŞDEĞER DEVRESI (STRUCTURE OF PV, MATHEMATICAL MODEL TAKE OUT AND EQUIVALENT CIRCUIT)

\subsection{Güneş Pilinin Çalışma Prensibi (Working Principle of Solar Cell)}

Bilindiği üzere, güneş pilleri üzerine düşen güneş enerjisini elektrik enerjisine çeviren bir p-n yariiletken aygıttır. Güneş pilleri katmanlı yapıda olup üst katman optik pencere katman1, alt katman ise temel katman olarak adlandırılır. Güneşten gelen 1şık tanecikleri (fotonlar) optik pencere tarafından soğrulmaktadır. Soğrulmuş fotonlar atomlara çarparak elektron boşluk çifti oluşturmaktadır. Elektronlar p-n eklem bölgesinde oluşan elektriksel alanın etkisiyle geçide doğru sürüklenmektedir. Geçitte oluşan elektriksel alanın yönü azınlık yük taşıyıcılarının (p-tipi malzeme için azınlık yük taşıyıcısı elektronlar, n-tipi malzeme için azınlık yük taşıyıcısı boşluklar) geçide doğru hareketi yönündedir. Bu süreç esnasında geçitten geçen yük taşıyıcıları fotovoltaik akım ve gerilim oluşturmaktadır. $\mathrm{Bu}$ fotovoltaik değerlerden üretilen akımı soğurucu bölge, üretilebilecek gerilimi ise geçitte oluşan engel geriliminin yüksekliği belirler. Şekil 1 fotovoltaik güneş pilinin çalışma prensibini göstermektedir.

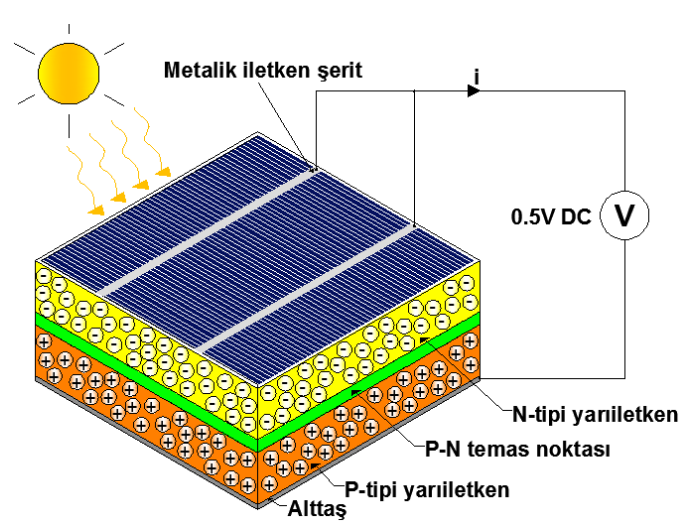

Şekil 1. Güneş pilinin çalışma prensibi (Working principle of solar cell)

\subsection{FV Sistem Bileşenleri ve Bağlantı Çeşitleri (PV System Components and Connection Types)}

Bir güneş hücresi çıkışında yaklaşı olarak 0.5 Volt civarında bir gerilim üretir [22]. Elde edilen gerilim yâda akım çıkışını arttırmak ve daha fazla güç elde etmek için hücreler seri veya paralel bağlanarak güneş pili modülleri, modüller bir araya getirilerek güneş panelleri ve çok sayıda panelin birleştirilmesi ile daha büyük yüzeyli güneş dizileri elde edilebilir [23].

Hücrelerin seri bağlanması bir hücrenin pozitif (+) yönünün, diğer hücrenin negatif (-) yönü ile bağlanmasıyla Şekil 2(a) da ki gibi gerçekleştirilir. Üretilen akım tek bir yoldan gideceği için ilk hücredeki akım ikinci ve üçüncü hücrelerin de üzerinden aynı şekilde geçer. Dolayısıyla güneş hücreleri seri bağlandıklarında sadece toplam gerilim artmış olur. Burada üretilen akım ise sabittir ve devrenin her yerinde aynı değerdedir [24]. Panellerin seri bağlanmasının dezavantajı, panellerin herhangi birinde kısmen gölgede kalma durumunda olduğu gibi bir aksama, panellerin tümü etkilenmişçesine sistem performansını olumsuz etkileyecektir [25]. Paralel bağlama ise bir hücrenin pozitif $(+)$ kısmının, diğer hücrenin pozitif (+) kısmına, negatif (-) kısmının ise diğer hücrenin negatif (-) kısmına bağlanmasıyla Şekil 2(b) deki gibi gerçekleştirilir. Burada üretilen elektrik akımı tek bir yolu takip etmez. Kaynakların birbirlerine paralel bağlandığı durumda akım artarken, gerilim ise sabit kalır. Sistemden elde edilmek istenen akımın artması için hücrelerin veya panellerin birbirlerine paralel bağlanması gerekmektedir [21, 24].

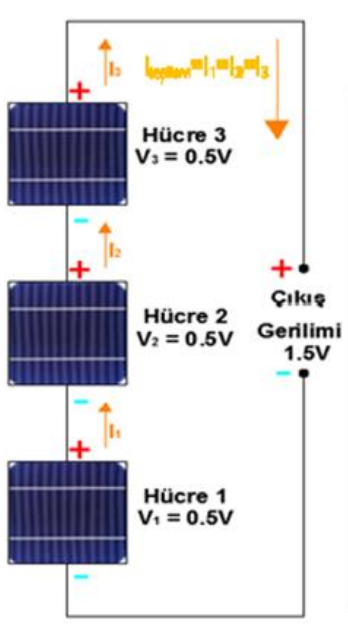

(a)

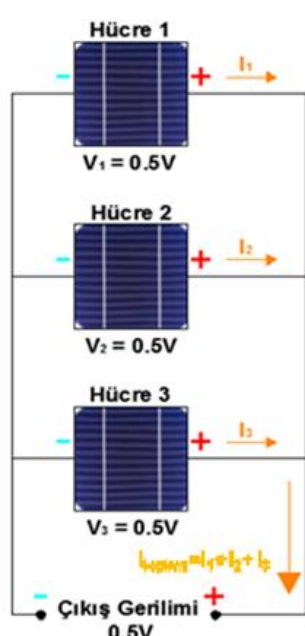

(b)
Şekil 2.Güneş pillerinin, (a) seri ve (b) paralel bağlanması (Series (a) and parallel $(b)$ connection of solar cells) [21]

\subsection{Güneş Pili Modeli ve Eşdeğer Devresi (Solar Cell Model and Equivalent Circuit)}

Güneş pilleri karanlık ortamda aktif olan bir aygıt değildir ve bir diyot gibi çalışır. Herhangi bir akım yâda gerilim üretemez. Buna rağmen dışardan bir gerilim kaynağına bağlanırsa bir I_D akımı üretir, bu akım diyot akımı veya karanlık akımı olarak bilinir [26].

Bir güneş hücresinin I-V karakteristik eğrisi Shockley diyot eşitliği ile Eşitlik 1'deki gibi ifade edilir.

$$
I_{D}=I_{S}\left[\exp \left(\frac{q V}{k T}\right)-1\right]
$$

Burada $I_{S}$ karanlık doyum akımı, $q$ elektron yükü, $V$ diyot gerilimi, $k$ Boltzmann sabiti, $T$ güneş pilinin sıcaklığıdır. 


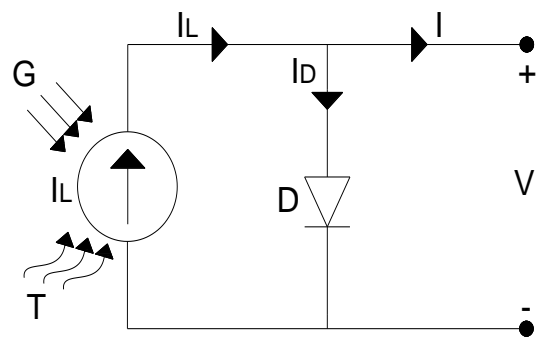

(a)

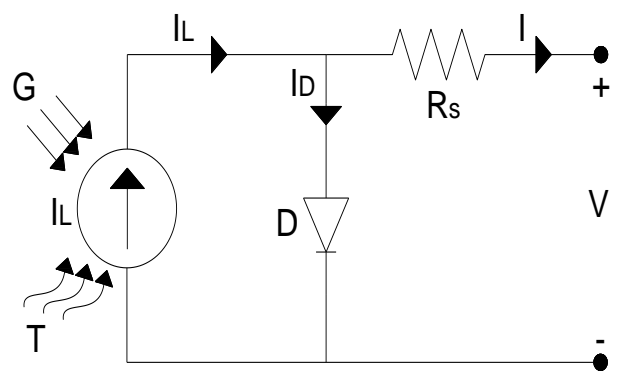

(b)

Şekil 3. (a) İdeal diyot modeli, (b) Basitleştirilmiş eşdeğer devre modeli ((a) Ideal diode model, (b) simplified equivalent circuit model) [6]

Net akım $(I)$, fotoakım $\left(I_{L}\right)$ ile diyot akımı $\left(I_{D}\right)$ arasındaki farka eşittir ve net akımın ifadesi Eşitlik 2'deki gibidir. Burada $n$ ideallik faktörü ve $R_{S}$ seri direnç olup güneş pilinin özelliğine göre bu parametreler değişmektedir. Eşitlik $3, V_{t}$ termal gerilimini ifade etmektedir.

$$
\begin{gathered}
I=I_{L}-I_{D}=I_{L}-I_{S}\left[\exp \left(\frac{\left(q\left(V+R_{S} \cdot I\right)\right.}{n \cdot k \cdot T}\right)-1\right] \text { (2) } \\
V_{t}=\frac{n \cdot k \cdot T}{q}
\end{gathered}
$$

Is karanlık doyum akımı olup sıcaklığa bağlı ifadesi verilecek olursa [27];

$$
\begin{aligned}
& I_{S}=I_{S\left(T_{1}\right)} \cdot\left(\frac{T}{T_{1}}\right)^{\frac{3}{n}} \cdot e^{-q E_{g} / n k\left(1 / T-1 / T_{1}\right)} \\
& I_{S\left(T_{1}\right)}=I_{S C\left(T_{1}\right)} /\left(e^{q V_{O C\left(T_{1}\right)} / n k T_{1}}-1\right)
\end{aligned}
$$

Kullanılan model güneş 1şınımı ve sıcaklık değişimi gibi güneş pilinin verimini etkileyecek parametreleri de içeren genel güneş pili eşdeğer devre modelidir. Bu model Şekil 4'te gösterildiği gibi bir akım kaynağı $\left(I_{L}\right)$, buna paralel bağlı bir diyot ve direnç $\left(R_{S h}\right)$ ve bir seri dirençten $\left(R_{S}\right)$ oluşmaktadır.

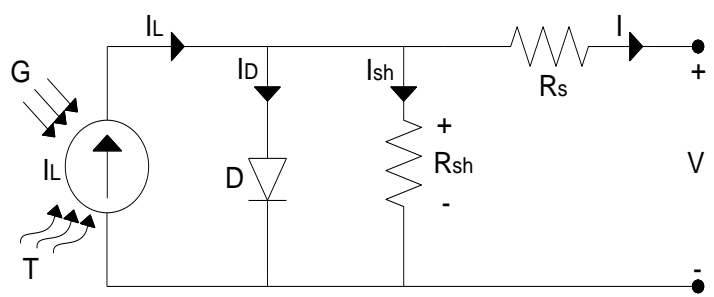

Şekil 4. Güneş pili eşdeğer devre modeli (Solar cell equivalent circuit model) [6]

Eşitlik 4 ve 5'te T1 güneş pilinin referans hücresel çalışma sıcaklığıdır. Şekil 4'teki güneş pili eşdeğer devre modeline göre net akım ifadesi verilecek olursa:

$$
\begin{gathered}
I=I_{L}-I_{D}-I_{s h} \\
I_{D}=I_{S}\left[\exp \left(\frac{\left(q\left(V+R_{s} \cdot I\right)\right.}{n \cdot k \cdot T}\right)-1\right] \\
I_{S h}=\frac{V+R_{s} \cdot I}{R_{s h}} \\
I=I_{L}-I_{S}\left[\exp \left(\frac{\left(q\left(V+R_{s} \cdot I\right)\right.}{n \cdot k^{T} T}\right)-1\right] \\
-\frac{V+R_{s} \cdot I}{R_{s h}}
\end{gathered}
$$

Burada $R_{s h}$ paralel direnç olup güneş pilinin özelliğine göre değişen bir parametredir. Güneş pilinin gerilim ifadesi Eşitlik 9 kullanılarak gerekli matematiksel işlemler yapılırsa Eşitlik 10'daki gibi yazılabilir. Burada paralel direnç $\left(R_{s h}\right)$ ihmal edilmiştir.

$$
V=\frac{n \cdot k \cdot T}{q} \ln \left[\frac{I_{L}+I_{s}-I}{I_{S}}\right]-R_{s} \cdot I
$$

Güneş pili eşdeğer devre modelindeki seri direnç $\left(R_{S}\right)$ yüke aktarılan akımdan kaynaklı güneş pilinin kayıplarını ifade eder ve maksimum güç üretimi için küçük olmalıdır. Bu diyota paralel bağlı $\left(R_{s h}\right)$ direnci ise toprağa aktarılan kaçak akımlardan kaynaklı güç kayıplarını gösterir ve çok küçük değerli olduğundan dolayı genelde ihmal edilir [20]. Maksimum güç $\left(P_{\max }\right)$ Eşitlik 11'deki gibi yazılabilir.

$$
P_{\text {max }}=V_{o p t} \cdot I_{o p t}
$$

Güneş pilinin verimi ise güneş piline aktarılan güç ile güneşten soğrulan ışı gücü arasındaki oran olup ve Eşitlik 12 'de gibi verilmişstir. Bu eşitlikte $G$ 1şınım şiddeti, $A$ ise hücrenin kesit alanıdır. 


$$
\eta=\frac{P_{\text {max }}}{P_{\text {in }}}=\frac{V_{o p t} \cdot I_{o p t}}{G \cdot A}
$$

Diğer bir parametre ise doldurma faktörüdür ve Eşitlik 13 'teki

gibi yazılabilir.

$$
D F=\frac{P_{\text {max }}}{V_{o c} \cdot I_{s c}}=\frac{V_{o p t} \cdot I_{o p t}}{V_{o c} \cdot I_{s c}}
$$

Eşitlik 14'de güneş pilinin hücresel çalışma sıcaklığ $1(T)$ ve güneş 1şı̆̆ı soğrulması ( $G$ ) ye bağlı akım ifadesi verilmiştir Burada $K_{1}$ kısa devre akımı için sıcaklık katsayısıdır. Bir diğer parametre ise rüzgâr hızı olup daha önce yapılan çalışmalarda 1-3 m/s aralığında seçilmiş olup ihmal edilebilir değerdedir [20, 28].

$$
I_{L}=\left[I_{s c}+K_{1}\left(T-T_{r e f}\right)\right] \cdot G
$$

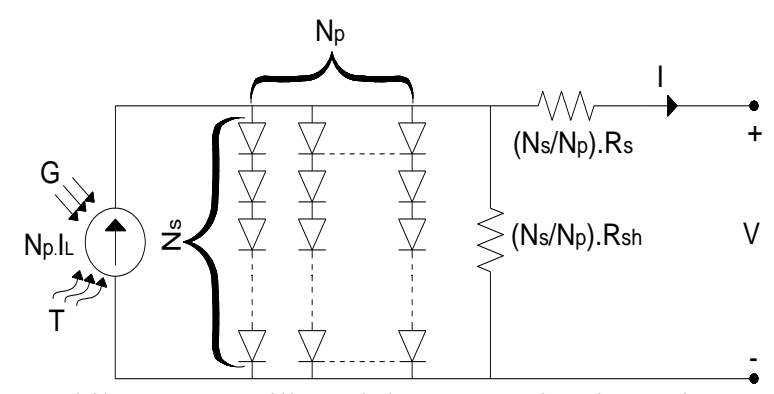

Şekil 5. Güneş pili modülünün genel eşdeğer devre modeli (General equivalent circuit model for solar cell module).

Eşdeğer devre modelinde yer alan seri hücre sayısı $\left(N_{s}\right)$ ve paralel hücre sayısı $\left(N_{p}\right)$ olarak alınıp Eşitlik 9'a uyarlanırsa oluşan bu model için toplam akım ifadesi Eşitlik 15'teki gibi elde edilir [29].

$$
\begin{gathered}
I=N_{P} \cdot I_{L}-N_{P} \cdot I_{S}\left[\exp \left(q \cdot \frac{\left(\frac{V}{N_{S}}+\frac{I \cdot R_{S}}{N_{P}}\right)}{k \cdot T_{C} \cdot A}\right)-1\right] \\
-\frac{\left(\frac{N_{P} \cdot V}{N_{S}}+I \cdot R_{S}\right)}{R_{S H}}
\end{gathered}
$$

Güneş pili eşdeğer devresindeki $R_{s}$ direnci $R_{s h}$ direncine göre çok daha küçük değerli olduğu için $R_{S h}$ direnci $R_{S}$ direnci yanında çok büyük $(\infty)$ yani açık devre gibi düşünülerek ve toplam modül akımı (I) Eşitlik 16'daki gibi yazılabilir.

$$
I=N_{P} \cdot I_{L}-N_{P} \cdot I_{S}\left[\exp \left(q \cdot \frac{\left(\frac{V}{N_{s}}+\frac{I \cdot R_{S}}{N_{P}}\right)}{k \cdot T_{C} \cdot A}\right)-1\right]
$$

Eşitlik 16'da $V=V_{F V}, I=I_{F V}, A=n$ ve $T_{C}=T$ ifadeleri yerine yazılarak toplam modül için çıkış gerilimi (VFV) Eşitlik 17'deki gibi olur.

$$
\begin{aligned}
V_{F V}=\frac{N_{S} \cdot n \cdot k \cdot T}{q} \ln \left[\frac{\left(I_{L}+I_{S}\right) N_{P}-I_{F V}}{I_{S} \cdot N_{P}}\right] \\
-\frac{N_{S}}{N_{P}} R_{S} \cdot I_{F V}
\end{aligned}
$$

Eşitlik 14'teki ifade, Eşitlik 17'de yerine yazılacak olursa güneş pili modülünün gerilim ifadesi Eşitlik 18 'deki gibi olur.

$$
\left.\begin{array}{c}
V_{F V}=\frac{N_{S} \cdot n \cdot k \cdot T}{q} \ln \left[\frac{\left(\left(I_{s c}+K_{1}\left(T-T_{r e f}\right)\right) G+I_{s}\right) N_{P}-I_{F V}}{I_{s} \cdot N_{P}}\right] \\
-\frac{N_{S}}{N_{P}} R_{S} \cdot I_{F V}
\end{array}\right]
$$

\section{FV HÜCRE ÇIKIŞ AKIMININ NEWTON- RAPHSON YÖNTEMİ İLE HESAPLANMASI (CALCULATION OF PV CELL OUTPUT CURRENT BY NEWTON-RAPHSON METHOD)}

Newton-Raphson yöntemi lineer olmayan denklem sistemlerinin çözümü için kullanılır. Bu yöntem denklemlerin nümerik analizi için kullanılan en güçlü yöntemlerden birisidir. Güneş pilinin standart test koşulları altında I-V eğrisinin benzetimini elde etmek için verilen her bir gerilim değeri için akımının hesaplanması gerekir [21]. Güneş pilinin akım ve gerilimi arasındaki bağıntı Eşitlik 19'daki gibi lineer olmayan bir denklemle tanımlanır. Bu denklemin çözümü için Newton-Raphson yöntemi kullanılmıştır. $\mathrm{Bu}$ yöntemin kullanılmasıyla hem pozitif hem de negatif akımların hızlı bir şekilde hesaplanması sağlanmıştır.

$$
\begin{gathered}
f(V, I)=N_{P} \cdot I_{L}-N_{P} \cdot I_{S}\left[\exp \left(q \frac{\left(\frac{V}{N_{S}}+\frac{I \cdot R_{S}}{N_{P}}\right)}{k \cdot T_{C} \cdot A}\right)-1\right] \\
-I=0
\end{gathered}
$$

Eşitlik 19'daki denklem çözümü için aşağıda verilen iterasyon işlemi uygulanırsa:

$$
I_{n+1}=I_{n}-\frac{f\left(V, I_{n}\right)}{\frac{d f\left(V, I_{n}\right)}{d I}}
$$

Eşitlik 16 kullanılarak, verilen hücre gerilimine karşılık gelen akım değeri Eşitlik 20'daki iterasyon işlemi ile bulunabilir 


$$
I_{F V(1)}=I_{F V}-\frac{N_{P} \cdot I_{L}-I_{F V}-N_{P} \cdot I_{s}\left[\exp \left(q \cdot \frac{\left(\frac{V_{F V}}{N_{s}}+\frac{I_{F V} \cdot R_{s}}{N_{P}}\right)}{k \cdot T_{C} \cdot A}\right)-1\right]}{-1-\frac{N_{P} \cdot I_{S} \cdot R s \cdot q}{k \cdot T c \cdot A}\left[\exp \left(q \cdot \frac{\left(\frac{V_{F V}}{N_{s}}+\frac{I_{F V} \cdot R_{s}}{N_{P}}\right)}{k \cdot T_{C} \cdot A}\right)\right]}
$$

FV hücre çıkış akımının Newton-Raphson tekniğiyle hesaplanışının akış diyagramı Şekil 6'da verilmiştir. Akış diyagramında görüldüğü üzere ilk olarak FV sistem sabitleri ve değişkenleri programa girilir ve programda fotoakım $\left(I_{L}\right)$, karanlık doyum akımı $\left(I_{S}\right)$ ve termal gerilim $\left(V_{T}\right)$ hesaplanır. FV hücre akımını hesaplamak için Eşitlik 16'ya for döngüsü içinde Newton Raphson metodu uygulanır ve bu işlem $\mathrm{j}=5$ olana kadar devam eder, $\mathrm{j}=5$ olunca hesaplanan FV hücre çıkış akım değeri simülatör ekranında gösterilir. Burada literatüre yapılan farklı çalışmalar dikkate alınarak döngü sayısı beş olarak seçilmiştir [27, 30, 31].

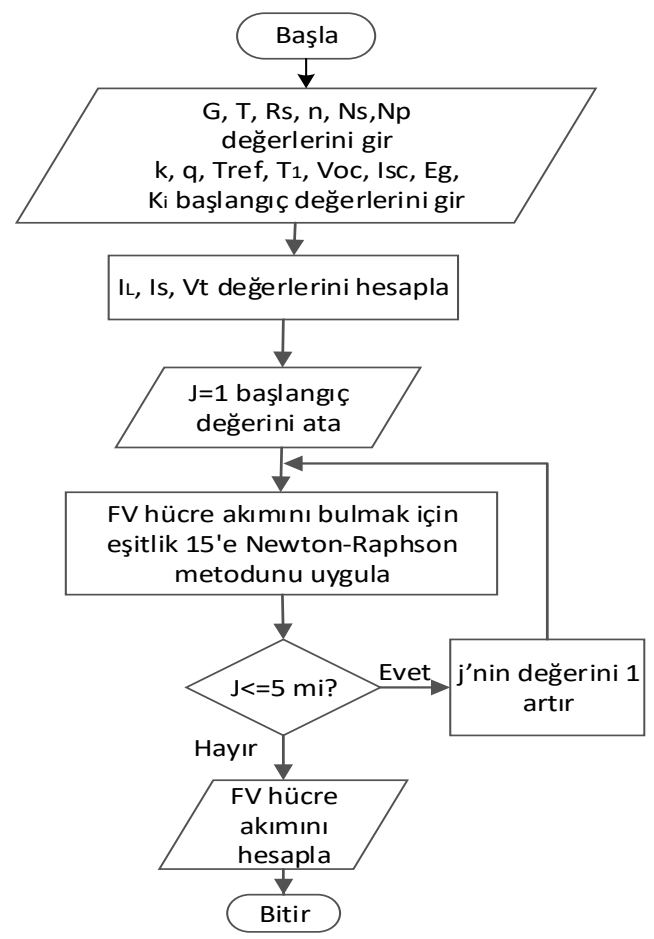

Şekil 6. Hücre akımı hesaplaması için Newton Raphson yöntemi akış diyagramı (Newton Raphson method flow chart for cell current calculation).

\section{MATLAB/GUI ORTAMINDA OLUŞTURULAN FV SISTEM SIMUÜLATÖRÜ (PV SYSTEM SIMULATOR CREATED IN MATLAB / GUI ENVIRONMENT)}

3.1. Güneş Pilinin MATLAB/GUI Arayüz Tasarımı (MATLAB/GUI Interface Design of Solar Cell)
Açılımı "Graphical User Interface" (GUI) olan ve içeriğinde yer alan nesnelerin kullanılması ile kullanıcıya etkileşim sağlayan ve bir programın koşturulmasını sağlayan grafiksel bir program ara yüzüdür. GUI nesneleri menüler, araç çubukları, butonlar, liste kutuları veya kaydırıcılar olabilir ve bunların yanında GUI arayüz ile MATLAB' in sunduğu hesaplama imkânları kullanılarak da veri alımı ve grafik çizimi gibi pek çok işlem gerçekleştirilebilir. Her bir nesne GUI için tanımlanan programlama dosyasında callback diye adlandırılan ayrı alt rutin programlama parçalarına sahiptir. $\mathrm{Bu}$ şekilde her bir nesnede oluşan olaylar için, GUI o olaya ait callback rutinlerini icra ettirir. Yani, GUI hem bir arayüz hem de bir program çağrılarını icra ettirme mekanizması olarak çalışır MATLAB GUI tasarımları iki ayrı yöntem kullanılarak yapılabilir:

- MATLAB GUIDE aracı kullanılarak,

- M-File programlama yöntemi kullanılarak.

Özellikle GUI tasarımında hızlı ara yüzler tasarlamak için MATLAB GUIDE aracının kullanılması büyük bir kolaylık sağlar ve sürükle bırak olarak çalışır. M-File programlama yönteminde ise tüm GUI tasarımları ve callback program parçalarının yazılması programlama kodları kullanılarak yapılır. Burada tasarımc1 her şeye egemendir ve bu teknik uzman bir programlama bilgisi gerektirir ancak programcı her türlü değişikliği yapabilir.

GUIDE MATLAB'ın GUI tasarımcılarına sunduğu içerisinde çeşitli araçlar içeren ve kolaylık sağlayan bir grafiksel GUI geliştirme ortamıdır. GUIDE kullanılarak tıkla ve sürükle-bırak tekniği ile GUI ara yüzüne; butonlar, metin kutuları, liste kutuları, grafikler gibi nesneler kolaylıkla eklenebilir. MATLAB GUIDE aracını çalıştırmak için ya MATLAB komut satırından GUIDE komutu girilir ya da Start düğmesi tıklanarak MATLAB/GUIDE komutu verilir ve Guide Quick Start penceresi açılır. $\mathrm{Bu}$ pencereden eğer yeni bir GUI tasarımı yapılacak ise Blank GUI seçeneği seçilir. Şayet önceden yapılmış bir tasarımı açmak isteniliyor ise Open Existing GUI sekmesinden sonra istenilen dosya seçilir. Bundan sonra GUIDE LAYOUT Editor (GUIDE Çalışma Alanı) penceresine ulaşılır. Eleman eklemek için sol tarafta bulunan nesne butonlarından istenilen nesneye ait buton tıklanır ve çalışma alanında uygun görülen bir noktaya tıklandığında Şekil 7 deki gibi elemanlar eklenecektir.

Bir GUI ara yüzünün programlanması demek o çalışmanın kaydedildiği isimle aynı zamanla oluşturulan .m uzantılı dosya içerisine kodlama satırlarının eklenmesi demektir. Bu dosyanın içine görebilmek, değişiklik yapabilmek için GUIDE 
çalışma ekranı penceresinden View/M-File Editor komutu işletilebilir. Burada pek çok kodun hazır MATLAB GUIDE tarafindan eklenmiş olduğu görülür. Burada ilgili butonlara ve liste kutularına ya da istenilen bir nesneye ait callback isimli alt program parçalarına ilgili kodlar yazılacaktır.

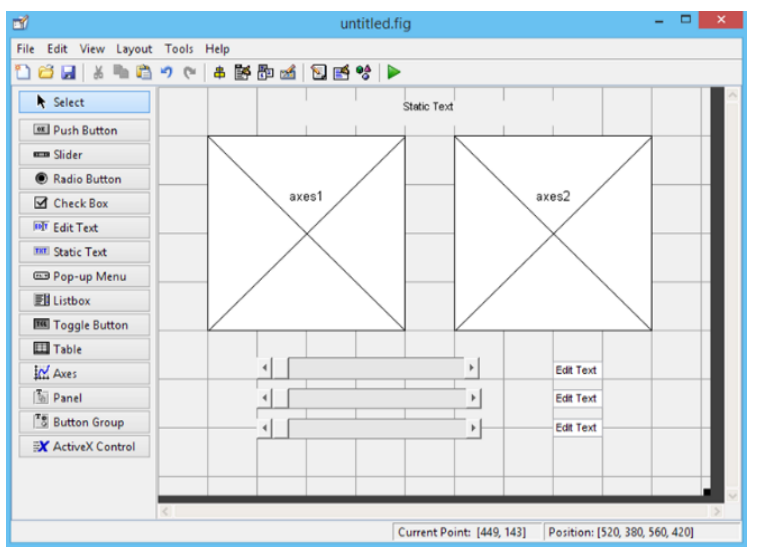

Şekil 7. GUIDE çalışma alanı ve elaman ekleme (GUIDE workspace and adding components).

Bir nesneye ait callback' in bulunduğu satıra gitmek için araç çubuğunda yer alan $f$ simgeli butona tıklanır ve açılan listeden ilgili nesneye ait callback' in ismi seçilerek ya da GUIDE çalışma ekranından ilgili nesnenin üzerine sağ tıklanarak da istenilen bir callback satırına gidilebilir. Oluşturulan ara yüzde bir nesneye ait callback alt program kodu ve oluşturulan fotovoltaik güneş pili modülü matematiksel modeline ait .m dosyasının bir kısmı aşağıda verilmiştir.

a) Oluşturulan ara yüzde bir nesneye ait callback alt program kodu:

$\%$--- Executes on slider movement.

function slider1_Callback(hObject, eventdata, handles)

$\%$ hObject handle to slider1 (see GCBO)

$\%$ eventdata reserved - to be defined in a future version of

MATLAB

$\%$ handles structure with handles and user data (see GUIDATA) NumSliderVal=get(hObject,'Value'); \% Get the irradiance value of the slider

StrSliderVal=num2str(NumSliderVal); \% Transform it to string set(handles.edit1,'String',StrSliderVal); \% Put it the

correspondent Edit Text

DrawIV

$\%$ ReDraw I-V, P-V curves after updating the parameters

$\%$ Hints: get(hObject,'Value') returns position of slider

$\%$ get(hObject,'Min') and get(hObject,'Max') to determine range of slider

$\%$--- Executes during object creation, after setting all properties. b) Güneş pili modülü matematiksel modeline ait .m dosyasının bir kısmı:

Global G;

$\% \mathrm{G}$ : the value of the irradiance

$\mathrm{G}=($ get(handles.slider1,'Value') $)$;

$\%$ Drawing the I-V Curve

axes(handles.axes1)

$\%$ Choosing the axes 1

plot(V,I,'LineWidth',2,'Color','red')

set(handles.axes1,'Color',[0.306 0.3960 .58$]$ )

$\%$ change backgroud

title(' Fotovoltaik Hücre I-V Grafiği')

legend('I-V eğrisi');

xlabel('Gerilim(V)');

ylabel('Akım(I)');

axis auto;

grid on

$\%$ Area of the PV Cell

$\mathrm{A}=0.0169$;

set(handles.edit1,'string',A);

$\%$ Set the value in the edit text 1

Bölüm iki ve üçte verilen denklemler kullanılarak FV güneş pili modeli MATLAB programına uyarlandı. Bu programın analizi için MATLAB/GUI ortamında Şekil 8'deki gibi bir arayüz tasarlandı. Kullanıcı bu ara yüzü kullanmaya başlamadan önce FV sistem sabitlerini MATLAB programına girmelidir. Daha sonra tasarlanan arayüz ile güneş ışınımı, panel sıcaklığı, seri iç direnç, ideallik faktörü, seri ve paralel hücre sayıları gibi parametreleri değiștirilecektir. $\mathrm{Bu}$ parametrelerin $I-V, \quad P-V$ karakteristik eğrilerine, maksimum akıma $\left(I_{m p}\right)$, maksimum gerilime $\left(V_{m p}\right)$, maksimum güce $\left(P_{m p}\right)$, giriş gücüne $\left(P_{\text {in }}\right)$, doldurma faktörüne $(D F)$ ve verime $(\eta)$ olan etkisi incelenebilir.

\subsection{MATLAB/GUI Ara Yüzünde Gerçekleştirilen Simülasyonlar (Simulations Performed in MATLAB/GUI Interface)}

Genelde, güneş paneli üreticileri açık devre, kısa devre ve maksimum noktadaki akım ve gerilim gibi değerleri paylaşırken, fotoakım, doyum akımı, ideallik faktörü, seri ve paralel direnç gibi değerleri paylaşmaz [32]. Modellemede Panasonic marka VBHN330SJ47 model ve LG marka NeON® 2 model 330 W'lık güneş panelleri kullanılmıştır. Güneş panellerine ait veriler Tablo 1 ve Tablo 2'de ayrı ayrı verilmiştir [33, 34]. 


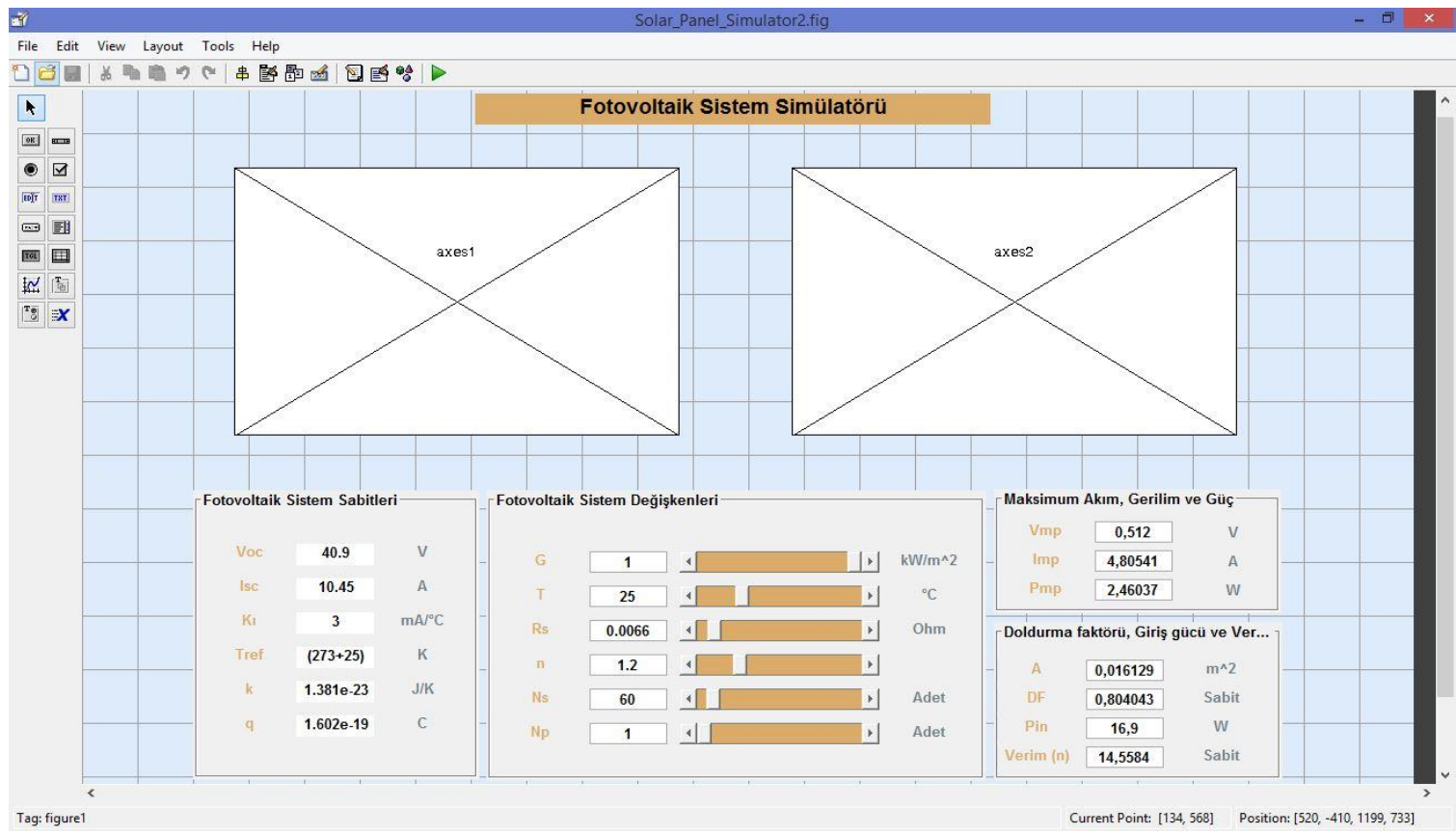

Şekil 8. Tasarlanan kullanıcı ara yüzü (Designed user interface)

Tablo 1. Panasonic VBHN330SJ47 güneş panelinin standart test koşullarındaki verileri (Data of Panasonic VBHN330SJ47 solar panel under standard test conditions) (1000 $\left.\mathrm{W} / \mathrm{m}^{2}, 25^{\circ} \mathrm{C}\right)[33]$.

\begin{tabular}{|l|c|}
\hline \multicolumn{1}{|c|}{ Güneş Panelinin Özellikleri } & Sayısal Dĕ̆grler \\
\hline Maksimum panel gücü $\left(\mathrm{P}_{\mathrm{m}}\right)$ & $330 \mathrm{~W}$ \\
\hline Maksimum güç akımı $\left(\mathrm{I}_{\mathrm{m}}\right)$ & $5.70 \mathrm{~A}$ \\
\hline Maksimum güç voltajı $\left(\mathrm{V}_{\mathrm{m}}\right)$ & $58.0 \mathrm{~V}$ \\
\hline Açık devre gerilimi $\left(\mathrm{V}_{\mathrm{oc}}\right)$ & $69.7 \mathrm{~V}$ \\
\hline Kısa devre akımı $\left(\mathrm{I}_{\mathrm{sc}}\right)$ & $6.07 \mathrm{~A}$ \\
\hline Güneş panel verimi $(\%)$ & 19.7 \\
\hline Hücre tipi $(\mathrm{HIT})$ boyutları & $127 \times 127 \mathrm{~mm}$ \\
\hline Hücre sayısı & $96(8 \times 12) \mathrm{Adet}$ \\
\hline Çalışma sıcaklık aralığı & $-40,+85{ }^{0} \mathrm{C}$ \\
\hline Kısa devre akımı sıcaklık & $3.34 \mathrm{~mA} /{ }^{0} \mathrm{C}$ \\
\hline
\end{tabular}

Tablo 2. LG NeON® 2 güneş panelinin standart test koşullarındaki verileri (Data of $L G N e O N \bowtie 2$ solar panel under standard test conditions $)\left(1000 \mathrm{~W} / \mathrm{m}^{2}, 25^{\circ} \mathrm{C}\right)[34]$.

\begin{tabular}{|l|c|}
\hline Güneş Panelinin Özellikleri & Sayısal Değerler \\
\hline Maksimum panel gücü $\left(\mathrm{P}_{\mathrm{m}}\right)$ & $330 \mathrm{~W}$ \\
\hline Maksimum güç akımı $\left(\mathrm{I}_{\mathrm{m}}\right)$ & $9.8 \mathrm{~A}$ \\
\hline Maksimum güç voltajı $\left(\mathrm{V}_{\mathrm{m}}\right)$ & $33.7 \mathrm{~V}$ \\
\hline Açık devre gerilimi $\left(\mathrm{V}_{\mathrm{oc}}\right)$ & $40.9 \mathrm{~V}$ \\
\hline Kısa devre akımı $\left(\mathrm{I}_{\mathrm{sc}}\right)$ & $10.45 \mathrm{~A}$ \\
\hline Güneş panel verimi $(\%)$ & 19.3 \\
\hline Hücre tipi (tek kristal) & $161.7 \times 161.7 \mathrm{~mm}$ \\
\hline Hücre sayısı & $60(6 \times 10) \mathrm{Adet}$ \\
\hline Çalışma sıcaklık aralığı & $-40,+90{ }^{0} \mathrm{C}$ \\
\hline Kısa devre akımı sıcaklık & $3 \mathrm{~mA} /{ }^{0} \mathrm{C}$ \\
\hline
\end{tabular}

Panasonic VBHN330SJ47 ve LG NeON® 2 model güneş panellerine ait parametreler ürün kataloglarından alınarak MATLAB programına girilmiş ve oluşturulan arayüz ile güneş paneline ait akım-gerilim $(I-V)$ ve güç-gerilim $(P-V)$ eğrileri, maksimum güç, maksimum akım ve maksimum gerilim, doldurma faktörü, giriş gücü ve verim değerleri sırasıyla Şekil 9(a) ve Şekil 9(b)'de elde edilmiştir. 


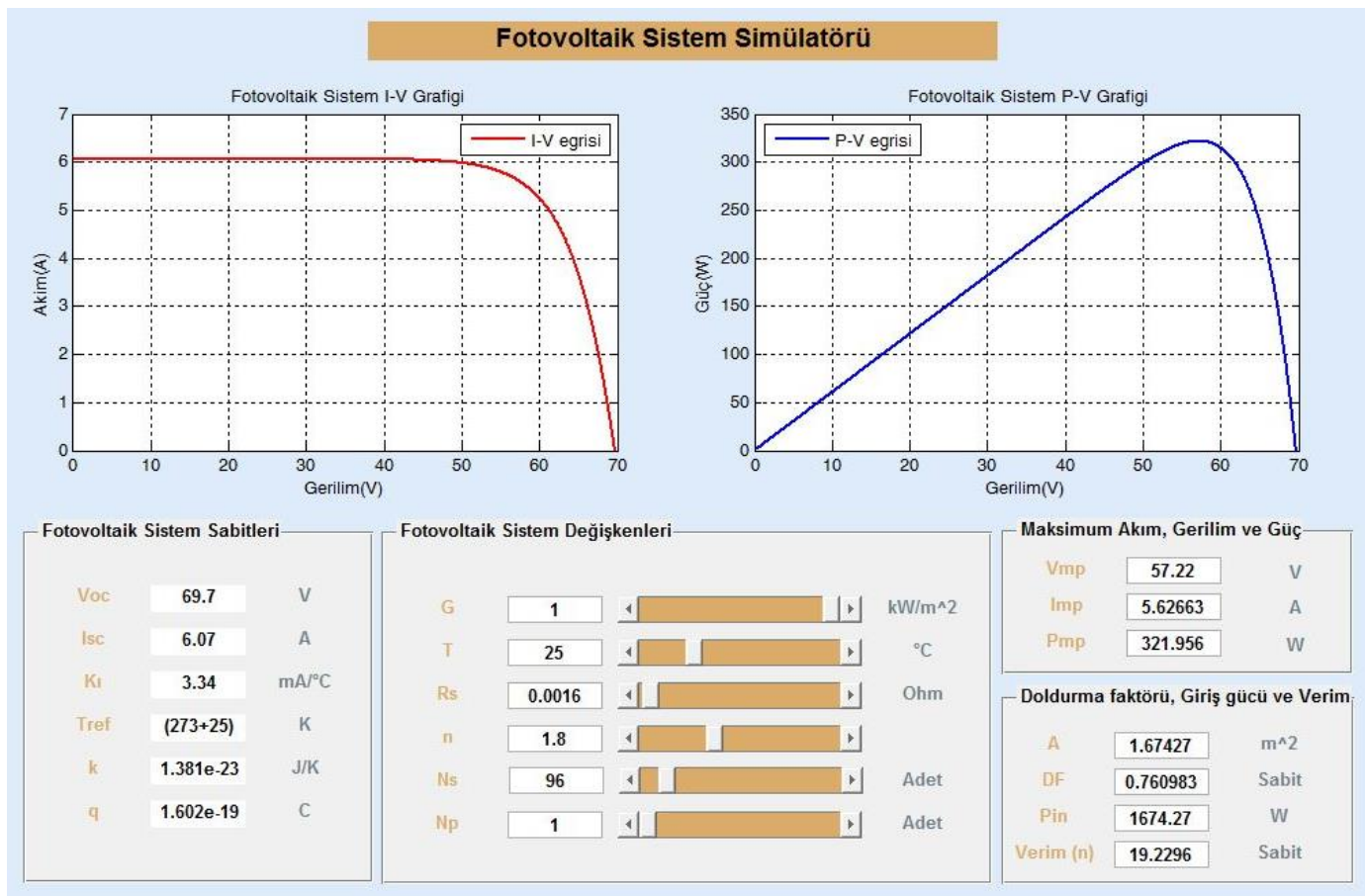

(a)

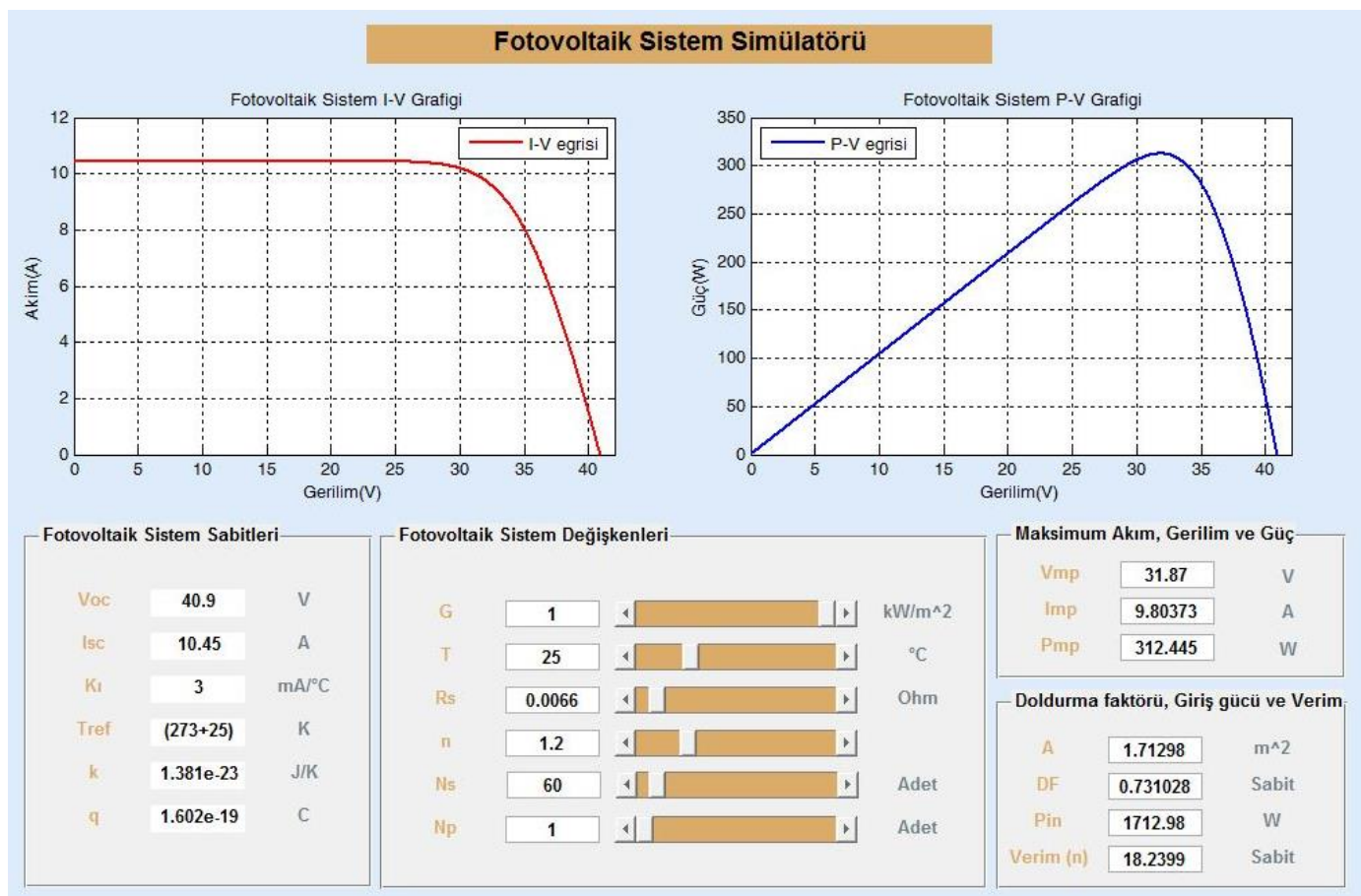

(b)

Şekil 9. (a) Panasonic VBHN330SJ47 güneş paneli için, (b) LG NeON® 2 güneş paneli için simülatörde $I-V$ ve $P$ - $V$ eğrisi çizimi ( I-V and P-V curve drawing for Panasonic VBHN330SJ47 (a), for LG NeON® 2 (b) solar panel in simulator).

Dört adet Panasonic VBHN330SJ47 ve LG NeON® 2 güneş panel seri bağlanmış ve akım-gerilim $(I-V)$ ve güçgerilim $(P-V)$ karakteristikleri sırasıyla Şekil 10 (a) ve
Şekil 10 (b)'de çizdirilmiştir. Şekil 10 (a) ve Şekil 10 (b)'de görüldüğü gibi seri hücre sayısı artarken açık devre gerilimi artmakta kısa devre akımı ise sabit kalmaktadır. 


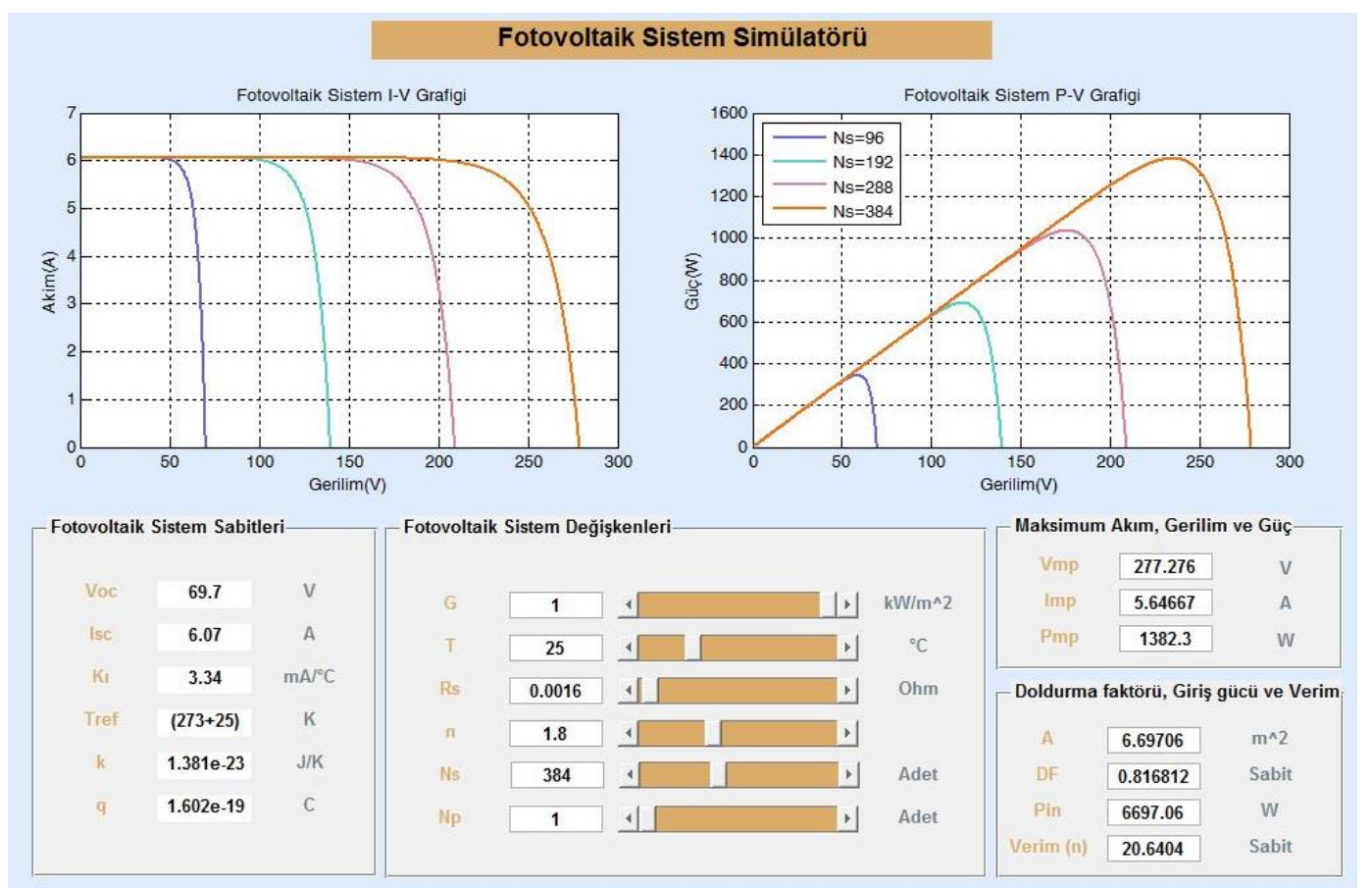

(a)

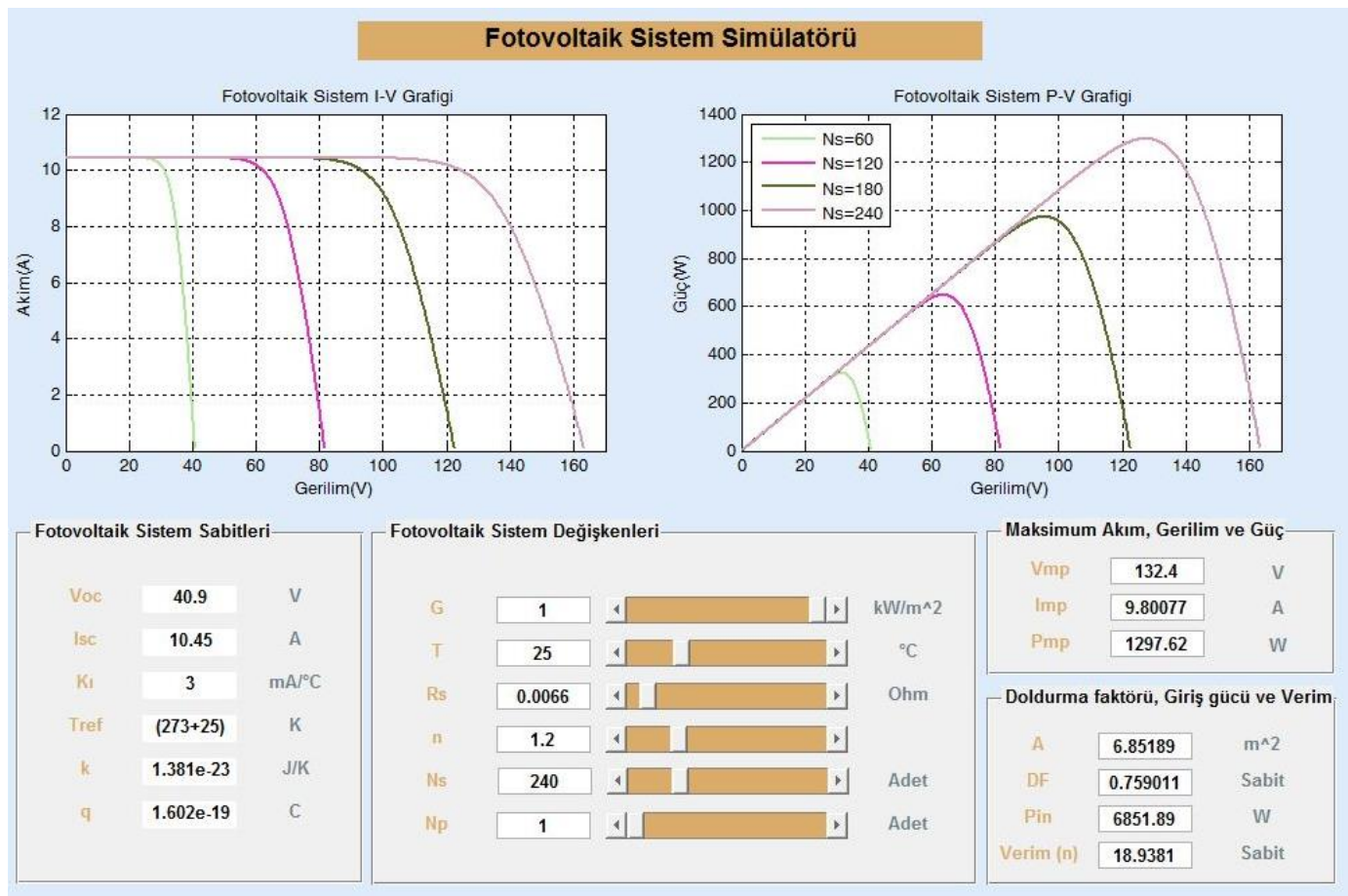

(b)

Şekil 10. (a) Panasonic VBHN330SJ47 güneş paneli için, (b) LG NeON® 2 güneş paneli için seri bağlantı $I-V$ ve $P$ - $V$ eğrisi çizimi (Serial connection $I-V$ and $P$ - $V$ curve drawing for Panasonic VBHN330SJ47( a), LG NeON® 2 (b) solar panel). 


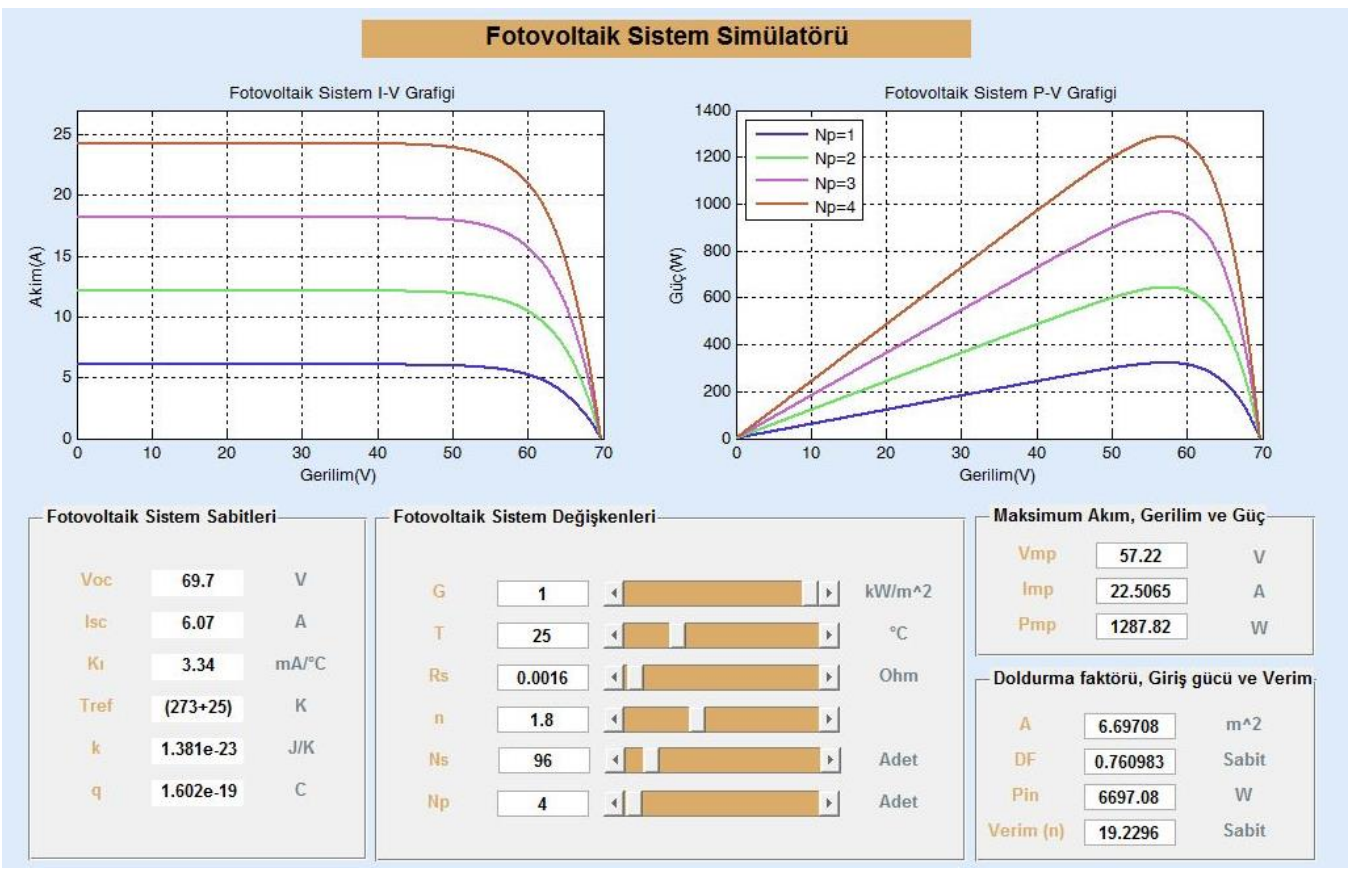

(a)

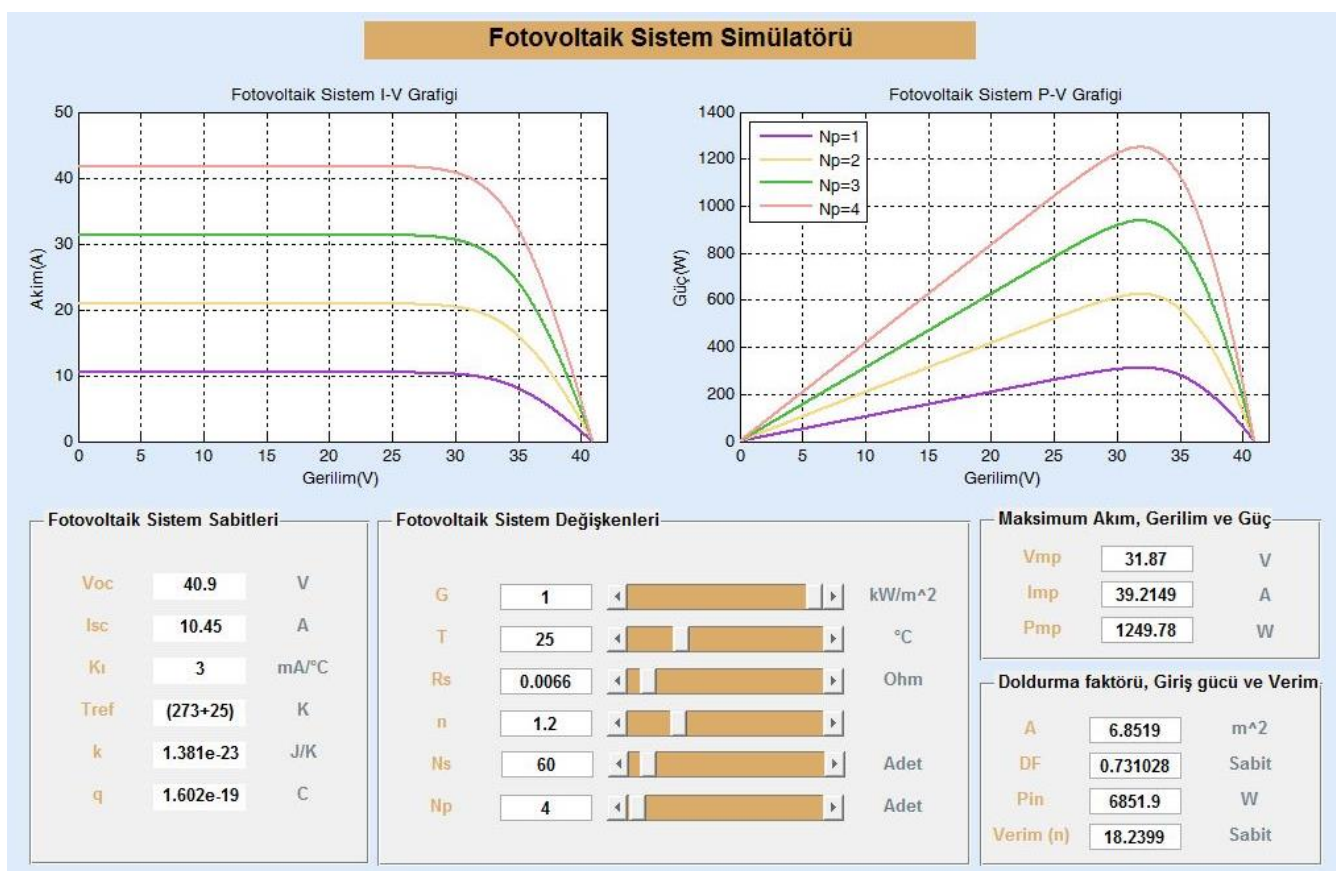

(b)

Şekil 11 (a) Panasonic VBHN330SJ47 güneş paneli için, (b) LG NeON® 2 güneş paneli için paralel bağlantı $I-V$ ve $P$ - $V$ eğrisi çizimi (Parallel connection $I-V$ and $P$ - $V$ curve drawing for Panasonic VBHN330SJ47( a), LG NeON® 2 (b) solar panel).

Şekil 11(a) ve Şekil 11(b)'de sırasıyla dört adet Panasonic VBHN330SJ47 ve LG NeON® 2 güneş panel paralel bağlanmış ve akım ile gerilim $(I-V)$ ve güç ile gerilim $(P-V)$ karakteristikleri çizdirilmiştir. Şekil 11 (a) ve Şekil 11 (b)'de paralel hücre sayıları arttığında akımın arttığı açık devre geriliminin ise değişmediği görülmektedir. Güneş pillerinin modellenmesindeki diğer bir parametre de ideallik faktörü olup 1,2 ile 5 aralığında değișir. Farklı ideallik faktörlerinde Panasonic VBHN330SJ47 ve LG NeON® 2 güneş panelleri için $I-V$ ve $P$ - $V$ karakteristik eğrileri Şekil 12(a) ve Şekil 12(b)'de gibi elde edilmiştir. İdeallik faktörüne bağlı olarak kısa devre akımı (Isc) ve açık devre gerilimi (Voc) değerleri de değişir. $\mathrm{Bu}$ artışa göre de maksimum güç aktarımı da Şekil 12(a) ve Şekil 12(b)'de ki gibi artmaktadır. 


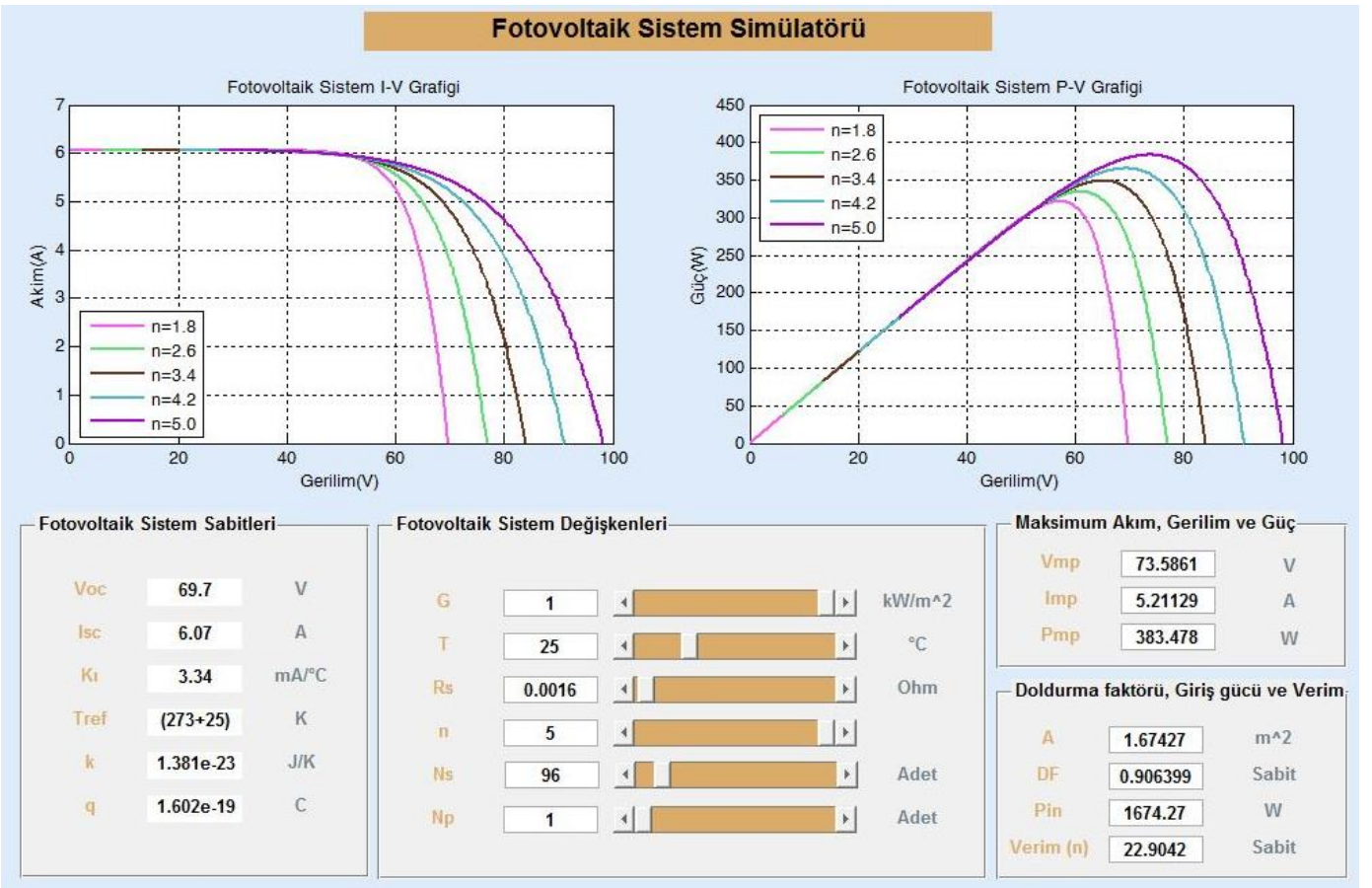

(a)

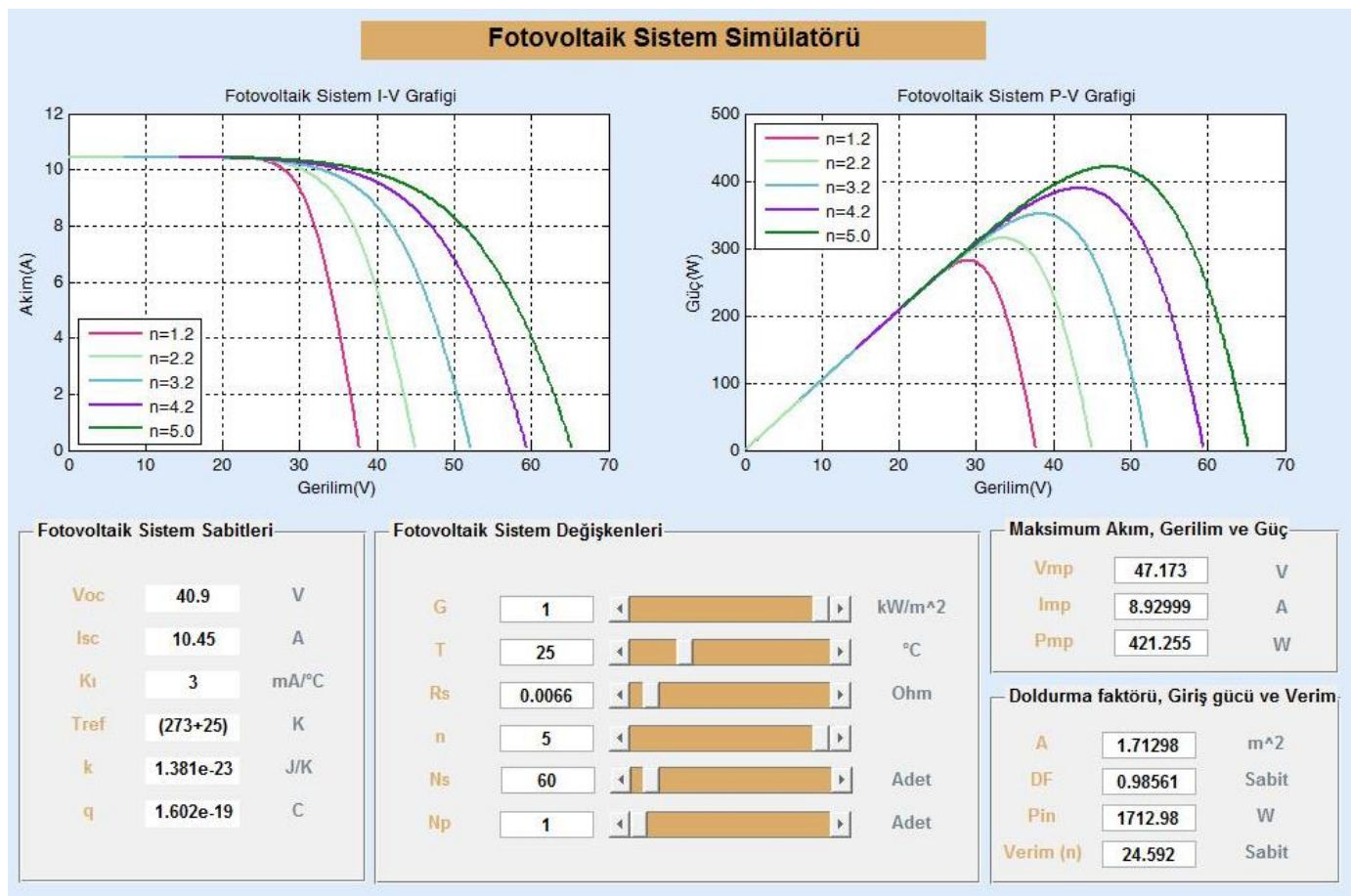

(b)

Şekil 12 (a) Panasonic VBHN330SJ47, (b) LG NeON® 2 güneş paneli için farklı ideallik faktöründe $I-V$ ve $P$ - $V$ eğrisi (I-V and P-V curve plotting at different ideality factor for Panasonic VBHN330SJ47 (a), and LG NeON® 2 (b) solar panel).

Panasonic VBHN330SJ47 ve LG NeON® 2 güneş panellerinin $I-V$ ve $P$ - $V$ eğrileri farklı seri iç dirençleri için Şekil 13(a) ve Şekil 13(b)'de sırasıyla çizilmiştir. Şekil 13(a) ve Şekil 13(b)'de görüldüğü gibi seri iç direnç $(R s)$ değeri ne kadar küçültülürse $I-V$ karakteristiğinin maksimum güç noktası açık devre gelimi ( $V o c)$ ve kısa devre akımı (Isc) değerlerine yaklaşmakta ve doldurma faktörü de büyümektedir. P-V eğrisinde de $R s^{\prime}$ nin değerinin azalması ile de maksimum güç noktası değeri de artmaktadır. 


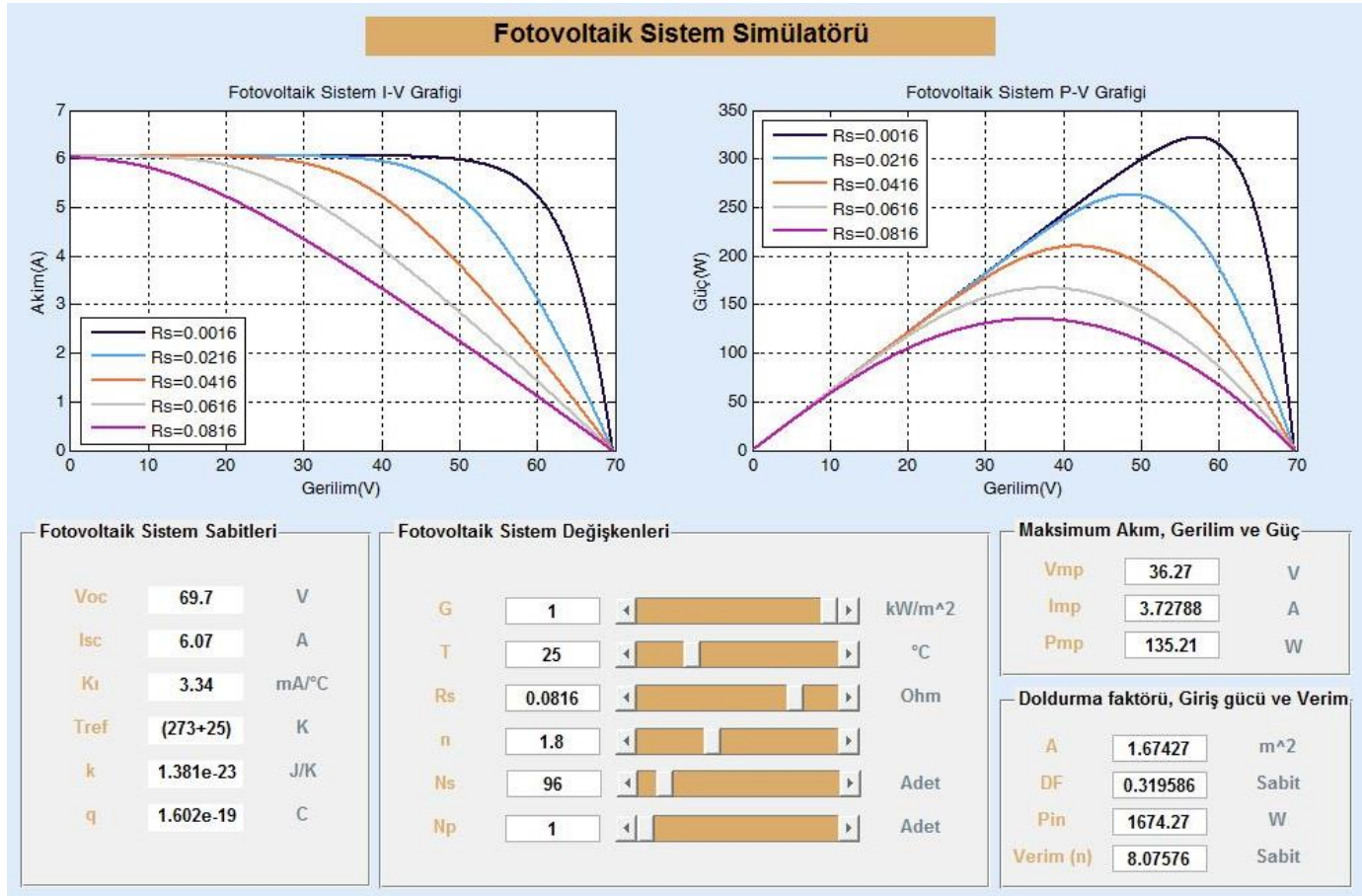

(a)

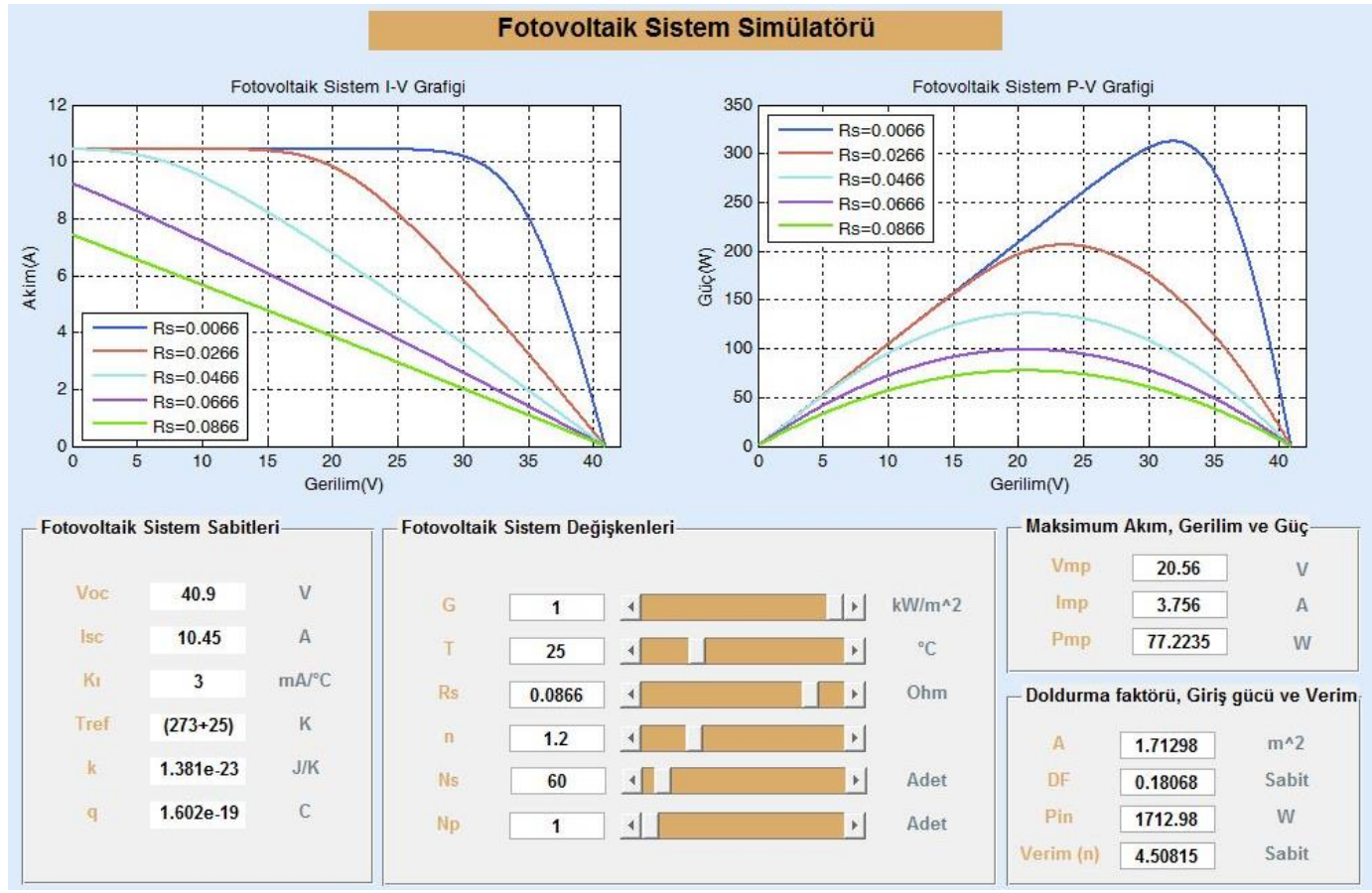

(b)

Şekil 13 (a) Panasonic VBHN330SJ47, (b) LG NeON® 2 güneş paneli için farklı iç direnç I-V ve P-V eğrisi çizimi (Different internal resistance I-V and P-V curve drawing for Panasonic VBHN330SJ47 (a), LG NeON® 2 (b) solar panel).

Șekil 14(a) ve Şekil 14(b)'de sırasıyla Panasonic VBHN330SJ47 ve LG $\mathrm{NeON}{ }^{\circledR} 2$ güneş panellerinin farklı sıcaklık değerleri için akım gerilim $(I-V)$ ve güç gerilim $(P-V)$ eğrileri gözükmektedir. Şekil 14(a) ve Şekil 14(b)'de güneş panellerinde sıcaklık artışının az miktarda da olsa açık devre gerilimi (Voc) nin değerini düşürdüğü kısa devre akımı (Isc) nin değerini ise artırdığı gözükmektedir. 


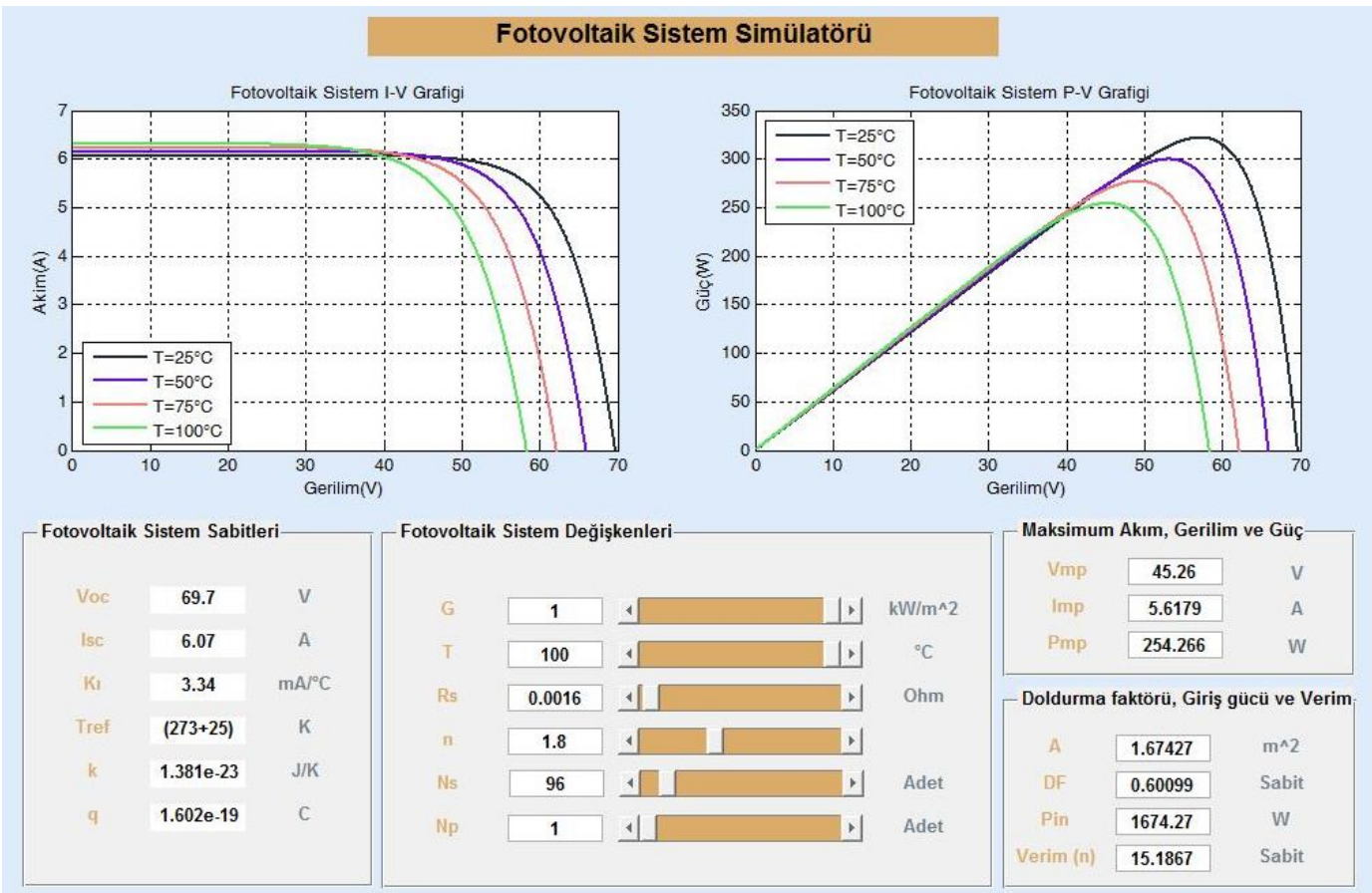

(a)

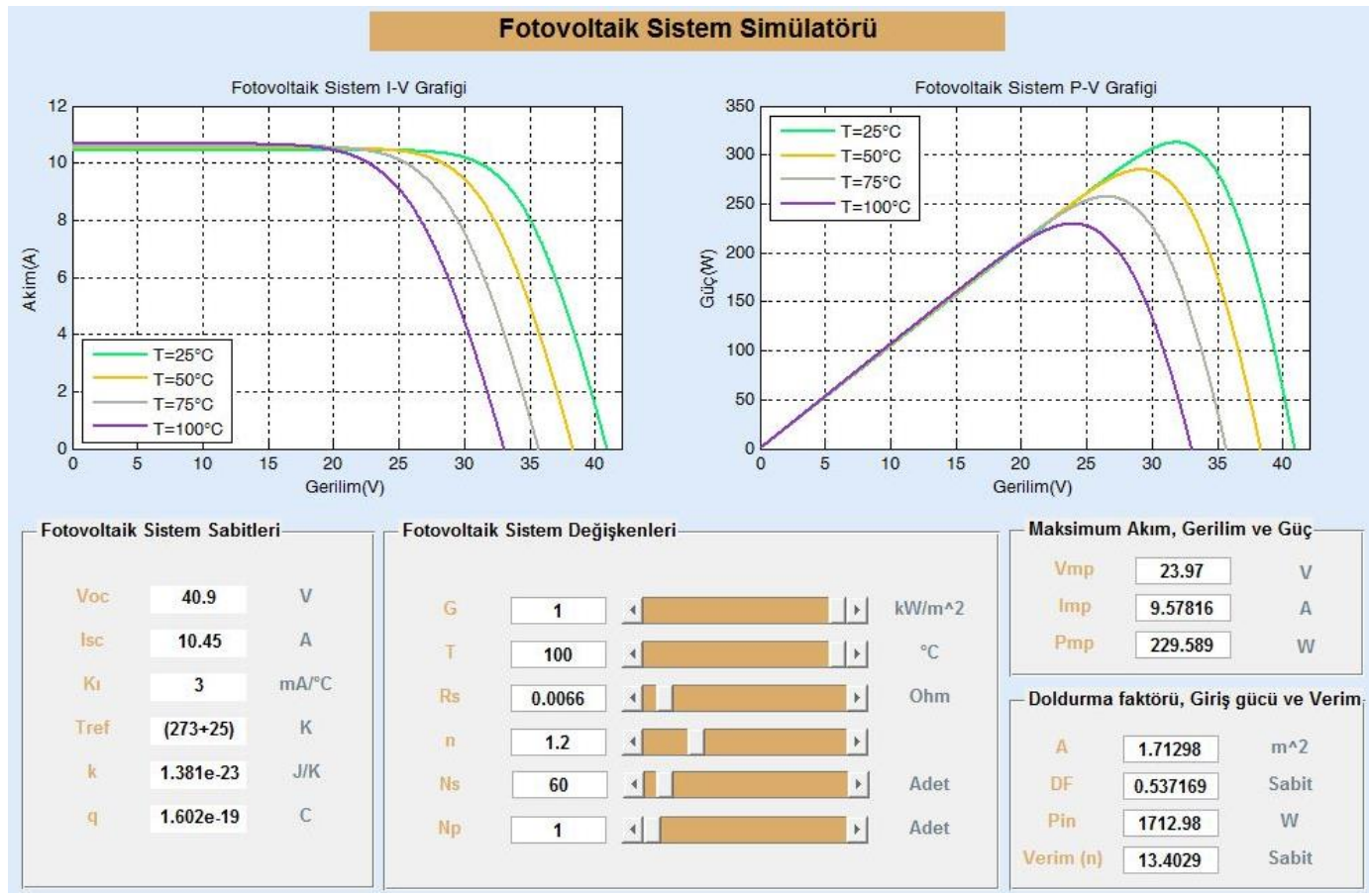

(b)

Şekil 14 (a) Panasonic VBHN330SJ47, (b) LG NeON® 2 güneş paneli için farklı sıcaklıklarda $I$ - $V$ ve $P$ - $V$ eğrisi çizimi (I-V and P-V curve plotting for Panasonic VBHN330SJ47 (a), LG NeON® 2 (b) solar panel at different temperatures).

Panasonic VBHN330SJ47 ve LG NeON® 2 güneş panellerinin farklı güneş 1şınım değerleri için $I-V$ ve $P-V$ eğrileri Şekil 15(a) ve Şekil 15(b)'de sırasıyla çizilmiştir. Güneş 1şınım değerleri $\mathrm{G}=0,2 \mathrm{~kW} / \mathrm{m}^{2}$ ile $\mathrm{G}=1$ $\mathrm{kW} / \mathrm{m}^{2}$ arasındaki değerler kullanılmıştır. Şekillerde

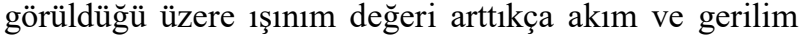
artmaktadır, fakat gerilim değerindeki artış akım değerine göre çok daha azdır. Akım ve gerilime artışı ile güç aktarımının da arttığı görülmektedir. 


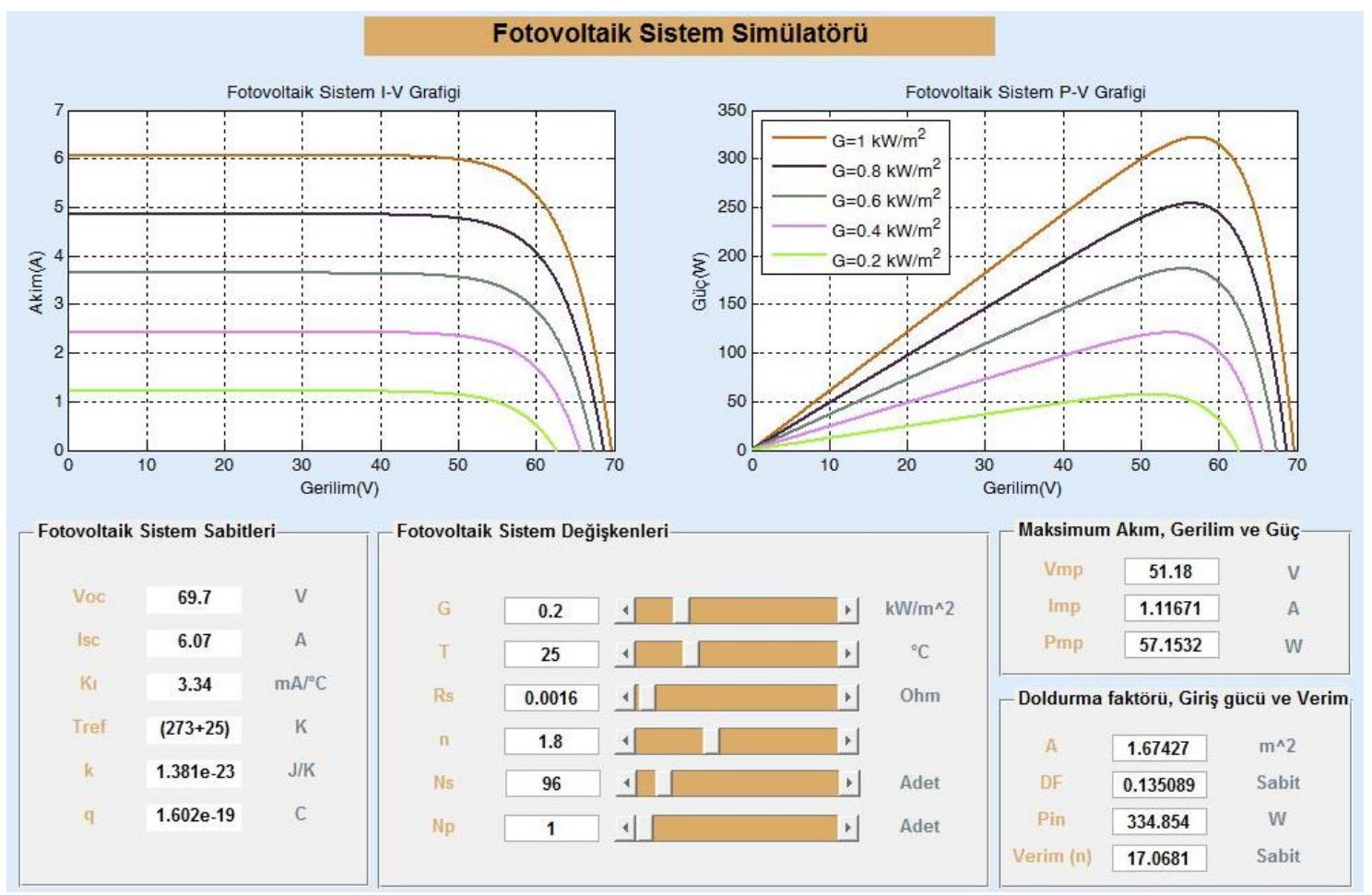

(a)

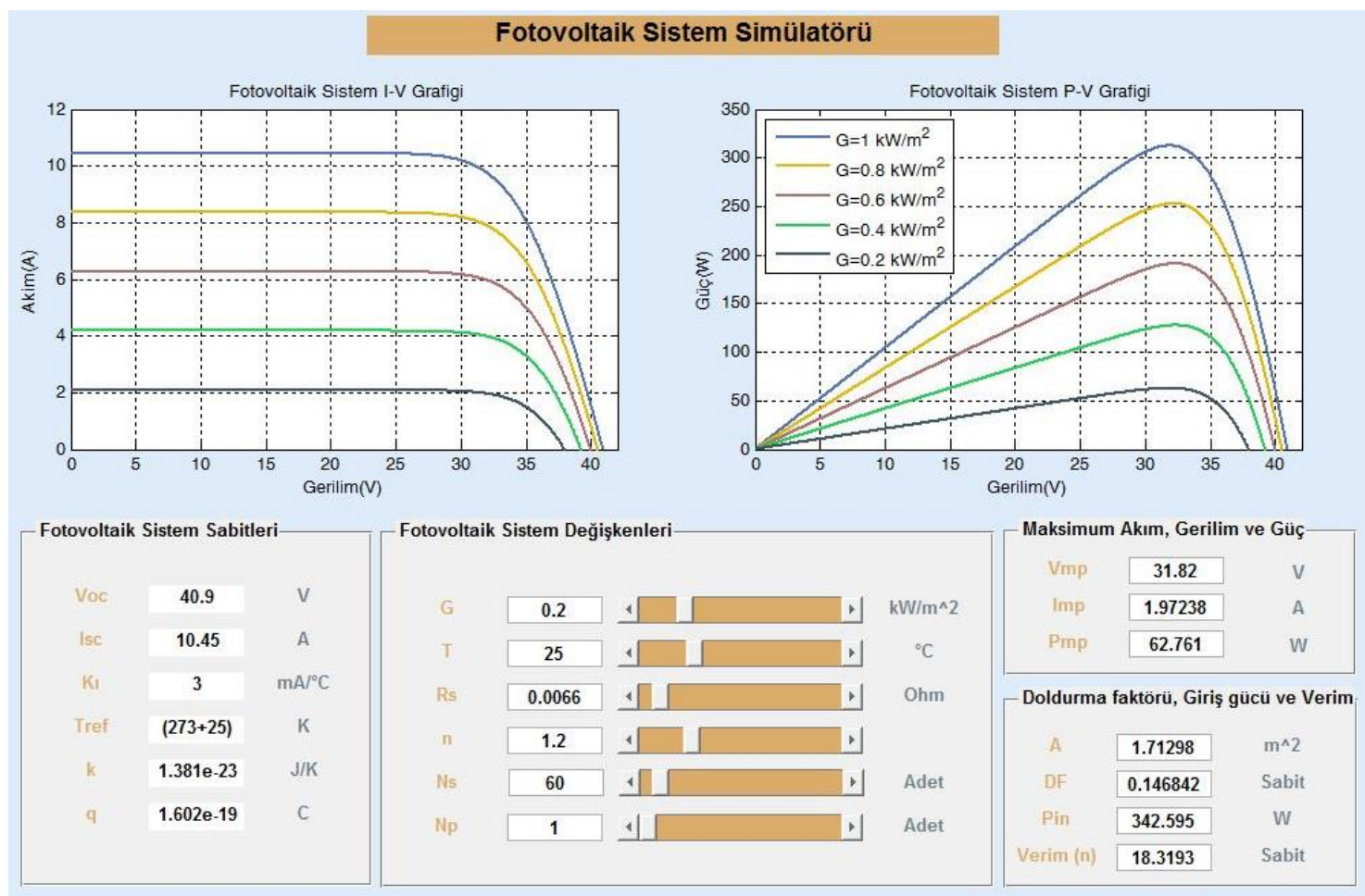

(b)

Şekil 15 (a) Panasonic VBHN330SJ47, (b) LG NeON® 2 güneş paneli için farklı 1şınımlarda $I-V$ ve $P$ - $V$ eğrisi çizimi (I-V and P-V curve drawing at different irradiations for Panasonic VBHN330SJ47 (a), LG NeON® 2 (b) solar panel).

\section{SONUÇLAR (CONCLUSION)}

Bu çalışmada, fotovoltaik güneş pillerine ait basitleştirilmiş eşdeğer devre modeli ele alınmış, güneş pilinin akım denklemi çözümü için Newton-Raphson yöntemi kullanılarak MATLAB/GUI ortamında bir ara yüz oluşturulmuştur. Oluşturulan arayüz ile 1şınım, sıcaklık, seri direnç, ideallik faktörü ve seri, paralel hücre 
sayıları gibi parametreler değiştirilerek akım ile gerilim $(I-V)$, güç ile gerilim $(P-V)$ eğrileri, maksimum akım $\left(I_{m p}\right)$, maksimum gerilim $\left(V_{m p}\right)$, maksimum güç $\left(P_{m p}\right)$, giriş gücü $\left(P_{i n}\right)$, doldurma faktörü $(\mathrm{DF})$ ve verim $(\eta)$ değerleri kolayca elde edilmiştir. MATLAB/GUI ara yüzü ile elde edilen sonuçlar ile FV güneş paneli üreticilerinin katalog verilerinin örtüştüğü görülmüştür. Bu sayede FV panel üreticileri ve araştırmacılar ile öğrenci laboratuvarları farklı parametrelerin değiştirilmesiyle FV sistem çıkış parametrelerinin nasıl değiştiğini anlayıp yorumlayabilecek ve sistemlerini buna göre tasarlayabileceklerdir. Ayrıca bu çalışmanın bu alandaki bilimsel araştırmalara da katkı sağlaması beklenmektedir.

\section{ÇIKAR ÇATIŞMASI BİLDİRIMI (CONFLICT OF INTEREST STATEMENT)}

Yazarlar tarafindan herhangi bir çıkar çatışması bildirilmemiştir.

\section{KAYNAKLAR (REFERENCES)}

[1] A. Koç, H. Yağlı, Y. Koç and İ. Uğurlu, "Dünyada ve Türkiye'de enerji görünümünün genel değerlendirilmesi” Mühendis ve Makina, vol. 59, no. 692, pp. 86-114, 2018.

[2] S. Ağıralioğlu, \& N. Ağıralioğlu, "Türkiye'de enerji ve politikaları” Takvim-i Vekayi, vol. 8, no. 2, pp.166-198, 2020 .

[3] U. Gürsoy, "Enerjide toplumsal maliyet ve temiz ve yenilenebilir enerji kaynakları" Türk Tabipleri Birliği Yayınları, Ankara, 2004.

[4] A. N. Akpolat, E. Dursun, A. E. Kuzucuoğlu, Y. Yang, F. Blaabjerg and A. F. Baba, "Performance analysis of a grid-connected rooftop solar photovoltaic system" Electronics, vol.8, no.8, pp. 905, 2019.

[5] M. E. Şahin and H. İ. Okumuş, "Modelling and simulation of solar cell module in MATLAB/Simulink" The Journal of Electrical, Electronics, Computer and Biomedical Engineering, vol. 3, no. 5, pp. 17-25, 2013.

[6] A. N. Akpolat, Y. Yang, F. Blaabjerg, E. Dursun and A. E. Kuzucuoğlu, "Modeling photovoltaic string in PLECS under partial shading" In 2019 International Conference on Power Generation Systems and Renewable Energy Technologies (PGSRET), August 2019, pp. 1-6.

[7] J. Patel, G. Sharma, "Modeling and Simulation of Solar Photovoltaic Module Using MATLAB/Simulink" International Journal of Research in Engineering and Technology, vol. 2, no. 3, pp. 225-228, 2013.
[8] N. Belhaouas, M. A. Cheikh, A. Malek, C. Larbes, "Matlab-Simulink of photovoltaic system based on a twodiode model simulator with shaded solar cells", Revue des Energies Renouvelables, vol. 16, no. 65, pp.73, 2013.

[9] A. Pandey, S. Devdas, "To study maximum power point tracking in photovoltaic cells" International Journal of Scientific \& Engineering Research, vol. 4, no. 6, 2013.

[10] E. Cuce, P. M. Cuce, I. H. Karakas and T. Bali, “An accurate model for photovoltaic (PV) modules to determine electrical characteristics and thermodynamic performance parameters" Energy Conversion and Management, vol. 146, pp. 205-216, 2017.

[11] I. H. Altas, A. M. Sharaf, "A photovoltaic array simulation model for Matlab-Simulink GUI environment" In 2007 IEEE International Conference on Clean Electrical Power, May 2007, pp. 341-345.

[12] V. Türkmenoğlu, F. Güngör, "MATLAB Simulink \& GUI with PV Cell Simulation" ELECO 2014, Bursa, Turkey, 27-29 November 2014, pp. 402-406.

[13] G. R. Walker, P.C. Sernia, "Cascaded DC-DC converter connection of photovoltaic modules" IEEE Transactions on Power Electronics, vol. 19, no. 4, pp.1130-1140, July 2004.

[14] V. Ouaschning, R. Hanitsch, "Numerical simulation of photovoltaic generators with shaded cells" Universities Power Engineering Conference, vol. 30, pp. 583-589, 1995.

[15] T. Tafticht, K. Agbossou, M. L. Doumbia, A. Chériti, "An improved maximum power point tracking method for photovoltaic systems" Renewable Energy, vol. 33, no. 7, pp. 1508-16. 2008.

[16] M. Benghanem, "Low cost management for photovoltaic system in isolated site with new IV characterization model proposed" Energy Conversion and Management, vol. 50, pp. 48-55, 2009.

[17] R. Bayindir, I. Colak, O. Kaplan, C. Can, "MATLAB/GUI based simulation for photovoltaic systems", In 2011 IEEE International Conference on Power Engineering, Energy and Electrical Drives, pp. 14, May. 2011.

[18] I. Issam Houssamo, F. Locment and M. Sechilariu, "Maximum power tracking for photovoltaic power system Development and experimental comparison of two algorithms" Renewable Energy, vol. 35, no.10, pp.2381$87,2010$. 
[19] G. Dzimano, "Modeling of photovoltaic systems" Master Thesis, Ohio State University, 2008.

[20] M. E. Şahin, H. İ. Okumuş, "Physical structure, electrical design, mathematical modeling and simulation of solar cells and modules" Turkish Journal of Electromechanics and Energy, vol. 1, no.1, 2016.

[21] M. B. Eteiba, E. T. El Shenawy, J. H. Shazly, A. Z. Hafez, "A photovoltaic (cell, module, array) simulation and monitoring model using MATLAB/GUI interface" International Journal of Computer Applications, vol. 69, no. 6, pp.14-28, 2013.

[22] S. Strong, W. Scheller, "The solar electric house" Sustainability Press, Massachusetts, 1993.

[23] G. Çelebi, "Using Principles of photovoltaic panels on vertical building envelope," J. Fac. Eng. Arch. Gazi Univ. vol.17, no. 3, 2002.

[24] D. Erdoğan, "Research on building integrated photovoltaic systems and their performance evaluation" Master Thesis, İstanbul Technical University, 2009.

[25] O. Bingöl, and B. Özkaya, “Analysis and comparison of different PV array configurations under partial shading conditions" Solar Energy, vol.160, pp. 336-343, 2018.

[26] A. D. Hansen, P. Sørenson, L. H. Hansen, H. Bindner, "Models for a stand-alone PV system", Risø National Laboratory, Roskilde, December 2000.

[27] E. Lorenzo, "Solar electricity engineering of photovoltaic systems" Artes Graficas Gala, S. L., Spain, 1994.

[28] M. E. Şahin, "Energy Management and Measurement of Computer Controlled Solar House Model for Rize City" Gümüşhane Üniversitesi Fen Bilimleri Enstitüsü Dergisi, vol. 10, no. 2, pp. 404-414, 2020.

[29] M. E. Şahin and F. Blaabjerg, "A hybrid PVbattery/supercapacitor system and a basic active power control proposal in MATLAB/Simulink" Electronics, vol. 9, no.1, pp. 129, 2020.

[30] S. Koohi-Kamali, N. A. Rahim, H. Mokhlis, and V. V. Tyagi, "Photovoltaic electricity generator dynamic modeling methods for smart grid applications: A review" Renewable and Sustainable Energy Reviews, vol. 57, pp. 131-172, 2016.

[31] A. O. Awodugba, Y. K. Sanusi, and J. O. Ajayi, "Photovoltaic solar cell simulation of Shockley diode parameters in Matlab" International Journal of Physical Sciences, vol. 8, no. 22, pp. 1193-1200, 2013.

[32] A. K. Ryad, A. M. Atallah, A. Zekry, "Photovoltaic parameters estimation using hybrid flower pollination with clonal selection algorithm" Turkish Journal of Electromechanics Energy, vol. 3, no. 2, pp. 15-21, 2018.

[33] Panasonic VBHN330SJ47, Available: https://www.europe-solarstore.com/panasonicvbhn330sj47.html. [Accesed: 22.05.2021].

[34] LG Neon 2 Black LG330N1K-V5, Available: https://www.lg.com/global/business/download/resources/ solar/NeON_2_60_BF_90214.pdf, 22.05.2021].

[Accesed:

This is an open access article under the CC-BY license (https://creativecommons.org/licenses/by/4.0/)

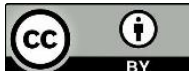

